\title{
Crossing takeover premiums and mix of payment: Empirical test of contractual setting in M\&A transactions
}

\author{
Hubert de La Bruslerie ${ }^{1}$
}

\begin{abstract}
The analysis of the offer premiums and of the means of payment should not be done separately. In the empirical literature these two variables are often considered independently although they may have endogenous relation in a contractual setting. Using a sample of European M\&As over the 2000-2010 decade, we show that these two variables are jointly set up in a contractual approach. The relationship of the percentage of cash with the offer premium is positive: higher premiums will yield payments with more cash.

We highlight that the payment choice is not a continuum between full cash and full share payment. The existence of two regimes of payment in M\&A transactions is the first conclusion we draw. We analyze the major determinants of M\&A terms when the offer premium and the means of payment are jointly set. The underlying rationale of asymmetry of information and risk sharing calculus is found significant in the setting of the agreement.
\end{abstract}

20/04/2011

Keywords : M\&A, takeover premium, means of payment, contract setting JEL: G32, G34

\footnotetext{
${ }^{1}$ Professor of Finance, DRM-Finance, University Paris-Dauphine, Place du Mal de Lattre 75116 PARIS (France) mail :hlb@dauphine.fr. I thank E. de Bodt, F. Riva, D. Isakov, M. Hoesli and J. Martel for their suggestions. This paper was presented at finance seminars at the University of Fribourg and at HEC Geneva, at the 2011 AFFI Conference at Montpellier, and at the 2011 CIG Conference at Montréal . The financial support of the Fédération Bancaire Française Chair in Corporate Finance is greatly acknowledged.
} 


\section{Crossing takeover premiums and mix of payment: Empirical test of contractual setting in M\&A transactions}

Introduction

The empirical literature privileges largely the acquirer's point of view: Why does he take the decision to bid for a target? How does he set his offered price? However, according Faccio and Masulis (2005), «In assessing potential determinants of an M\&A payment method, our focus is on a bidder's M\&A financing choices, recognizing that targets can also influence the final terms of an M\&A deal. » We will follow the latter's intuition by analyzing a (successful) takeover as a contractual agreement where both parties find enough interest to lead the offer to a success. The two key variables defining a contract are the takeover premium, and the offered means of payment. The basis of a contractual approach is that these key variables are jointly determined and agreed as a package. We will not follow the track of numerous empirical studies that looks individually at premiums or means of payment because such an approach is incomplete.

A M\&A is an economic project per se that bears some economic risk either for the target's shareholder or for the acquirer's shareholders. This new risk can be dealt with ex ante, at the contract setting using an appropriate choice of means of payment. Cash payment, i.e. receiving liquidity, is a way for the seller to avoid risk. For the same, shares payment is a way to bear some of the new risk introduced by the project. The M\&A project and the means of payment are linked together as part of the same global setting agreed between the seller and the buyer. The means of payment decision is a part of the contract, which is as important as the price itself. In a risk sharing perspective, the means of payment are ex ante choice to share the expected risk (and profit) from the transaction. This should be particularly true in mixed payment schemes where the relative percentage between shares and cash payment is an equilibrium variable. In these contexts, the package of mixed payment percentage and takeover premium will define the contract, and both will refer to asymmetry of information. The link between these two variables has not been extensively analyzed in the empirical literature. 
This paper tests the hypothesis of a global contractual setting linking the takeover offer premium and the means of payment. Empirical studies have often privileged the analysis of either the takeover premiums, or the means of payment. A joint empirical analysis is developed with regard to a sample of $528 \mathrm{EU}$ deals using systems of simultaneous equations. We show that offer premiums and means of payment interfere. We consider completed deals in the empirics of this paper. For a deal to succeed, it needs to satisfy both the bidder and the seller. Our findings support the view of M\&A deals as global contractual equilibrium.

The development will be divided into three parts. Section 1 proposes a review of the literature. Section 2 will present the sample and the variables. The empirical results are analyzed in the third section. A conclusion follows.

\subsection{Review of Literature}

The takeover premium and the mix of payment have often been considered in separate strands of the literature.

\subsection{Takeover premium}

Takeover premium have been extensively studies in the empirical corporate finance literature in relation to ownership structure or to acquirer's or target's characteristics.

\section{-) Ownership}

Takeover premium level is linked with the ownership structure of the target. The high bargaining power of large blockholder may force acquirers to higher bids (Stulz, 1988). The use of controlling devices such as double voting rights, separation of votes and cash flow rights may enhance that positive relationship. The existence of shareholders agreement is also viewed as an efficient mechanism of coordination inside the controlling group. It leads to higher firm valuation (Volpin, 2002; Belot, 2010), and it results in higher takeover premiums. Either the existence of an agreement between blockholders or the aggregate voting rights of the controlling party influences positively the takeover premium for French firms (Belot, 2010). However premiums are also the consequence of private benefits paid to the inside owners or to incumbent blockholders. The latter trade their benefits against a higher premium, otherwise the incumbent shareholder will not accept to loose their control and /or their private 
benefits. Bebchuk (1994), Burkard et al. (2000) or Burkart and Panunzi, (2004) support theoretically this view. Empirically, Moeller (2005) gives support to it.

Deal characteristics also are important. The contestability of the offer is an element leading to higher prices (Stulz et al., 1990; Song and Walking, 1993). The empirical literature documents a positive relation between the target cumulative abnormal returns and the competitive nature of the bid.

\section{-) Firms' characteristics}

When the target and the acquirer belong to the same economic sector, merging may yield economies of scale and higher profitability. The consistency of the project is measured by proximity or identity of the SIC codes of the buyer and the seller. Synergy gains will motivate higher bids by the bidder (Sundarsanam et al. 1996, Officer 2003). If the acquirer has already a stake of the target's capital, it will give him a possible access to inside information. The toehold is defined by the percentage of shares owned by the bidder; it will explain a lower asymmetry of information. Betton and Eckbo (2000) showed that a toehold influences negatively the takeover premium.

On the target's characteristics side, size is a traditional control variable. The premium is spread over a larger investment. In line with Officer (2003), the relationship between size and premium is expected to be negative. The financial leverage of the target is also important because it may signal a monitoring of the target firm by debtors. This is particularly true for controlled companies or family firms. It will limit private benefits and then explain lower premiums. On the other hand, higher debt leverage may be used as a power enhancing tool for the controlling group and consequently may help appropriating private benefits. Stulz (1988) mentions that target's entrenched controller may force a bidder to pay a higher premium. So the sign of the relationship is not defined.

The process of takeover develops in a context of a double information asymmetry between the acquiring and target firms. Hansen (1987) was the first to mention the so-called "double lemons effect", where each one has private information on his own value and has incomplete information on the nature of the assets he receives. The bidder buys assets of uncertain value. Being risk averse, he is willing to pay less when facing an information risk. He may also want to share the valuation risk by paying with equity of the newly merged group. The target's 
shareholders will receive shares based on a new economic project based on forecasted profits and synergies. They may also insure themselves by receiving cash and avoiding share payment. Asymmetries of information will explain the risk-sharing attitudes of the buyer and the seller and consequently the choice of a mix of payment (see below). Hansen (1987) measures the double asymmetry of information using the relative size of the target compared with the size of the bidder. The risk-sharing explanation is developed by Berkovitch and Narayanan (1990) who introduced the sharing of the synergy gains between the buyer and the target firm's shareholders into the analysis. The seller's appropriation of the synergy gains is linked to the difference in information between the two parties. Chang and Mais (1998) expanded the idea that an exchange of information can help to solve the problem of double information asymmetry. They introduced a prior holding in the target's capital ("toehold") as a means to reduce the buyer's asymmetry of information. In such a situation the buyer has a better inside knowledge of the target, especially if he holds a large portion of capital (Goldman and Qian, 2004). Cheng et al. (2008) used a sample of US firms to compare asymmetry of information, bid premiums and means of payment. They show that means of payment and bid premiums are interdependent, with means of payment conditioning heavily the price paid in the deal for a given asymmetry of information between the two parties. This suggests that the two terms are linked in a contract design perspective.

\subsection{Means of payment}

The literature devoted to means of payment follows another strand. A payment by shares has no consequence on the cash situation of the firm because the acquirers issues new shares. However, it may have consequence in terms of (i) signal to the firm's shareholders and (ii) wealth situation of the final shareholders because of the dilution of the perspectives in value creation.

In a M\&A decision, a bidder is facing a choice between using cash and stocks as deal payment consideration. This alternative choice has conflicting effects and follows different explanations. A first rationale ensues from the starting idea that the financing decision is separated from the investment decision. The M\&A project is first selected and then the acquirer considers ways to optimally finance the possible deal. The constraints here are the limits of the financial leverage or of the shareholder control structure of the bidder. Generally bidders have limited cash and liquid assets, so cash offers require debt or equity financing. 
The pecking order theory says that acquirers will first choose internal funds. These funds are available either as holdings or as internally generated cash flow. Initiators with cash availability will prefer cash payment (Martin, 1996). Partial or full payment in shares may express the existence of financial constraints (Myers and Majluf, 1984). However, equity financed transactions may yield problems in keeping up control when shareholding is concentrated. As Faccio and Lang (2002) pointed out, this situation occurs frequently in the EU. As a consequence, a bidder implicitly faces a choice of debt or equity financing, which involves a trade-off with corporate control concerns. Faccio and Masulis (2005) explain mixed payment in takeover by the structure of control and by the debt level of the acquiring firms. Their empirical tests on European mergers and acquisitions support the idea of a preference for a cash payment when there is a large shareholder owning $20 \%$ to $60 \%$ of the capital of the buyer. The bidder's M\&A currency decision is strongly influenced by his debt capacity and existing leverage. It can also be strongly influenced by entrenched managers or by the blockholder's desire to maintain the existing corporate governance structure.

Payments in cash, either full-cash or mixed cash payments, need to be financed. The literature analyzes classically means of payment without questioning the source of funding the M\&A transaction at the acquirer's level. The acquirer may issue and sell new equity stocks, or issue debt, or use the firm's cash holdings. Martynova and Renneboog (2009) analyzed the financing decision behind the choice of the means of payment in M\&A transactions. Externally financed M\&A are funded by $30 \%$ by equity and $70 \%$ by using debt. In a sample of Europeans deals they show that the financing decision and the choice of means of payment are driven by distinct determinants and are not interdependent. However, there show a significant evidence of an indirect and reverse influence of the means of payment on the internal/external financing choice. There is also an influence of the bidder's choice to share or not the risk of the transaction with the target's shareholders and/or to buy out these shareholders. In such a situation, equity payment and equity financing are privileged.

The means of payment choice is also sensible to the genuine context of the deal. Strategic competition between bidders is the first reason given to prefer cash. Fishman (1989) analyzes the strategic role of the means of payment in public takeover and considers that a pure cash offer is dissuasive and signals good quality target firms. However, his model leads to cashonly or share-only payments. Fishman relates the payment by cash to the future profitability of the target as expected by the competing bidders. Cornu and Isakov (2000) develop a model 
in a context of a competitive offer between two acquiring firms. The risk, when the first one sets a price offer and a means of payment, is to trigger a counter-offer by the other firm. In order to disclose information on his strategy, the first bidder can use a signal through an announcement of a pure cash payment or a pure share payment. However, the large majority of mergers and acquisitions are non-hostile and the means of payment are diversified. The characteristics of the payment scheme have to be analyzed in a context of a known success of the takeover

The portion of capital the bidder wants to receive (beyond gaining control) is an adjustment variable. That fraction reveals private information about the buyer's real value. If the means of payment disclose private signals to other parties, it will in return also influence the process of negotiation. Hansen's model explains the probability of paying in cash or in shares but does not focus on mixed-payment schemes. Double asymmetry of information may explain risk sharing choices and payment with shares issued by the initiator. Eckbo, Giammarino and Heinkel (1990) refer explicitly to the idea of an optimal mixed cash-shares payment. They were the first to highlight that the weighting between these two means of payment will reveal to other parties the respective quality of competitive buyers. Martin (1996) links the cash payment with private information: an acquirer with good growth opportunities will prefer a shares payment.

The empirical literature on means of payment identifies the existence of different rationale explaining the cash or the equity choice (Carleton et al., 1983). The cash paid acquisitions are found to have better performances after (Linn et al. 2001). The literature on mixed cashequity payments is relatively recent. On a factual ground, mixed payment schemes have become increasingly important in mergers and acquisitions, particularly when considering offers for large firms. Goergen and Renneboog (2004) analyzed public takeover bids in Europe during the 1990s. Looking at a sample of 156 offers, 93 were pure cash, 37 pure shares and 18 were mixed payment. Among the latter, the portion of cash accounted for $45.9 \%$ of the total payment. Faccio and Masulis (2005) considered a larger sample of 3,667 mergers or acquisitions of European firms at the end of the nineties. The number of mixed payment operations is only $11.3 \%$ (with an average proportion of $57 \%$ in cash and $43 \%$ in shares). The size of a mixed payment takeover bid was five times (1.1 billion USD) greater than the size of a standard pure cash offer (209 million USD). Mixed payment schemes 
represent a far greater proportion of transactions as the value of transactions rises ${ }^{2}$. However, this discrepancy is largely explained by cross-border transactions, where a large number of small deals are paid in cash. Comparing average relative sizes of the target with the acquirer gives similar results between mixed (16\%) and full-shares payments (18\%). Cash payments seem more devoted to relatively small targets, with an average relative size of $8 \%$ for transactions dealt fully in cash. In recent years, the number of mixed-payment takeovers has been increasing. Martynova and Renneboog (2006) considered 1,721 European takeovers between 1993 and 2001 and discovered that 54\% were all-cash, 25\% were mixed and 20\% were all-equity transactions. On average, the mixed payments comprised $47 \%$ of stocks and 53\% of cash. Ben-Amar and Andre (2009) examined 293 Canadian mergers and acquisitions over the period 1998-2002. The sample composition was 58\% cash-only, $19 \%$ stocks-only and $22 \%$ mixed payments. However, the latter represented $32.3 \%$ of the total value of the transaction, pointing out that mixed payment takeovers occur particularly in the higher value transactions. For mixed-payment takeovers, the average percentage of cash was $49 \%$ but with a standard deviation of $50 \%$, corresponding to huge differences within payment schemes.

Cross border M\&A are usually more paid in cash. This traditional setting is documented by Chevalier and Redor (2007). They show that geographical distance is a good proxy for cultural distance. It is also a source of asymmetry of information for transactions located in far countries. This explains why cross border acquisitions are per se more paid in cash. Their dependant variable is the percentage paid in cash for US acquiring firms and includes mixed payment. The target shareholders will prefer cash because shares from a foreign firm may be not easily traded. The quality of the assets of a far away company is more difficult to assess. The information asymmetry develops with distance as shown by Chevalier and Redor (2010). Conversely, tax system will favor equity payments. In European tax systems, the payment by cash is considered as sales and the shareholder will exhibit effective gains submitted to income tax. Share payments are exchange of assets and are not considered as taxable effective gains. The target's shareholders can defer later tax liabilities by accepting stocks as payment.

\subsection{The contractual nature of a M\&A transaction}

\footnotetext{
${ }^{2}$ The high number of all-cash takeovers in their sample is partly explained by the number of cross-border takeovers with US bidding firms, which are used to propose full payment in cash.
} 
The chosen means of payment may also reveal the specific characteristics of the transaction. An M\&A is an economic project and a contractual agreement with a seller. When it occurs, it signals a joint agreement between parties. The target's shareholders are not forced to sell (except in buyout transactions).

The risk of asymmetry of information is (partially) solved in such a contractual setting, by the level of the premium and by the choice of means of payment. La Bruslerie (2010) showed that choices are not univocal but occur in a process conveying private information from one party to the other. Mix of payment and takeover premium interfere. If the risk on the target's assets is important or if the acquirer is risk averse, he may prefer payment in shares. However if the perspectives of profit after the acquisition are large, the acquirer's shareholder will privilege a payment in cash in order to keep all the profit. Equilibrium between risk and return explains the choice between means of payment, and a trade-off will develop with the acquisition premium. If a buyer is insured against future bad news through a payment by shares, he can offer a better price. This equilibrium may give "corner solutions", i.e. either full cash or full share payments. But it may also lead to mixed payment were the percentage paid in cash is a relevant measure of information asymmetry. The same calculus is followed from an inverse point of view by the targets' shareholders. They are exposed to an information risk on the future gains in synergy and on the expected profit of the newly merged company. If they are expecting high profit or if they are delivered optimistic information, they will prefer share payment (for a given price paid). Except for corner solution where other determinants fully explains all-cash or all-shares payments, the percentage of cash in mixed payment schemes is part of the deal and defines the equilibrium concurrently with the agreed price.

In a model, La Bruslerie (2010) shows that, from the buyer's point of view, (i) correlated activities and economic risk between the target and the acquiring firms will result in a larger payment with cash; (ii) a trade-off develops between the percentage in cash and the premium paid in the acquisition. For the acquirer, the cash payment portion increases with the perspectives of profit due to synergy gains. The seller will accept a negative trade-off between a higher (lower) cash payment and a lower (higher) transaction price (i.e., a lower/higher portion of the expected acquisition gain). It is shown that mixed payment will only develop between "corner solutions" of full cash or full share payments, where the expected profit from the acquisition is between two limits. 
The regulatory environment may also play a significant role in the contract setting. Some countries developed investor protection regulations which facilitate M\&A transactions. In the European Union, a regulation is effective and gives strength to the protection of shareholders. It enforces an equal treatment principle between shareholders. The EU $13^{\text {th }}$ directive was formally adopted in 2000 and implemented in the European countries, although with some local difference. Any takeover bid or private acquisition should be analyzed by the EU administration and comply with anti monopoly rules. European financial regulation is made at the global level and tries to set up "a unique global financial market". The accounting policy in Europe should also comply with common rules. As an example, the introduction of the new common IFRS rules was enforced in 2005. Legal rules and procedures are taken at the countries level but must conform to the EU "directives". The introduction in the domestic law system of each country may also explain differences. La Porta, Lopez-de-Silanes, Shleifer, and Vishny (1998) highlight the importance of the legal system. However the legal code indicators, flagging Scandinavian, French, Anglo-Saxon or German origins, are found insignificant by Faccio and Masulis. We will thereafter limit the influence of regulatory environment by looking only to M\&A transaction targeted at firms located in the 7 major European countries (i.e. UK, France, Italy, Germany, Spain, Italy and Belgium). We will disregard the recent European becoming countries (such as Eastern Europe countries) or taxheaven countries (Luxembourg). The sample is then homogeneous with regard to the regulation context.

\section{Data and variables}

\subsection{Data}

The sample of European takeover was built from the Thomson One Banker date base. The period was limited to transactions between 01/01/2000 and 01/05/2010. A filter was used to focus on meaningful operations and a minimum value of 50 million USD is required. Only completed deals were considered. ${ }^{3}$ Target companies are limited to firms belonging to the seven EU major countries: France, Germany, United Kingdom, Spain, Belgium, Netherlands, and Italy. We select deals where the type of assets targeted by the acquirer is stock or

\footnotetext{
${ }^{3}$ The question of a bias in selecting our sample does not arise. We only consider as object of study are the agreed deals, i.e. deals were an agreement is found between the acquirer and the target. Not agreed deals are not completed. The ir analysis of their key variables and provisions is not relevant in a contract setting approach where an agreement reveals an economic equilibrium between the parties
} 
equivalent stocks (i.e. assets giving rights to stocks). The means of payment referred at are only cash or stock (see Annex 1).

We excluded offers coming from non developed countries, restricting to North American, European, or Japanese buyers. If the acquirer proposes his stocks as a valuable mean of payment, it requests that a large transparent and market exists for his stock to be accepted. This is why we restricted both targets and acquirers to be public firms. A sample of 528 transactions is followed. We checked the used mode of payment through the data. A lot of deals are qualified "cash only" or "stock only" in the data base. Mixed payment transactions have also been screened. Those qualified as "hybrid" show a payment scheme with a percentage of cash and stocks. We only consider "pure" mixed payment with a percentage of cash and a percentage of stock summing up to one. Some deals are qualified as "unknown". By looking at each operation syllabus we can allocated a lot of them to mix payment schemes. Deals with earn out payment considerations are excluded because of this uncertainty and complex features. Some transactions may involve payment in debt (particularly in the UK). This possibility is proposed alternatively with a cash payment. When analyzing deals with a debt payment, they generally appear to be equivalent to cash payment. So "cash payments" in the paper are defined as in Faccio and Masulis (2005) and includes cash, non-contingent liabilities and newly issued notes. We incorporate in the sample a lot of hybrid cash/debt/stock payment and recalculate the percentage of cash and shares summing up to one.

The Faccio and Masulis sample considered deals from European bidder directed to any country in the world. It gives a large weight to UK firm deals (65\% of the sample). We look at M\&A targeted at European firms from major developed countries. Similarly to Faccio and Masulis, our sample is mainly intra EU: in their sample $77 \%$ of the bids come from European countries, $79 \%$ in our sample.

Some deals were not documented without any price, or were initiated by Russian entities, or were squeeze out transactions ( 2 deals). ${ }^{4}$ They were not considered. So we are left with 504 transactions. The analysis of the sample leads to identify some transactions that are buyback

\footnotetext{
${ }^{4}$ We eliminated also buyout deals from the analysis. They are not transaction between shareholders of two different and independent firms. They are decisions made by managers on behalf of the controlling shareholders to buy the shares of the firm. It does not involve another party.
} 
programs launched by the company's board. Here the target's shares are the company's stocks or a subsidiary's. In these situations we do not have independent targets and acquirers. The buybacks were deleted (72 transactions). The remaining core of our sample is 432 transactions of which 294 full cash payment, 62 mixed cash-share (called "hybrid") and 76 full share payments. The global value of theses deals is 898 billions USD. Some big acquisitions will explain this amount: the biggest transaction is the Bencham/Glaxo acquisition and has a transaction value of 76 billions USD. The smallest operation shows a transaction value of 50.2 millions USD.

\subsection{Descriptive statistics}

When considering the 3 sub samples of full cash, full share and hybrid (i.e. mixed cash-share) payments, we point out differences in the average deal size (see Table 1). As in Faccio and Masulis, we find that cash deals are the most numerous but also have a relatively small size. Hybrid transactions are 3 times larger than cash paid deals (five times in the Faccio and Masulis' sample). Full share payments are important deals. The cumulated values of the deals paid fully either in cash or in stock, are equivalent (i.e. around $40 \%$ of the grand total each). The mixed payment transactions are not negligible; they represented a cumulated value of 211 billions USD and $24 \%$ of the total sample. A test of difference in size show that shares and hybrid transactions are not different $(\mathrm{p}=0.34)$, but the sizes between full cash and hybrid transactions, on one hand, and full cash and full share transactions, on the other hand, are different at the $5 \%$ level (both $\mathrm{p}=0.03$ ).

\begin{tabular}{llllll}
\hline & Number & \multicolumn{3}{c}{ Total value } & Av. deal size \\
\hline Cash & 294 & $68.1 \%$ & 365192 & $40.7 \%$ & 1242.15 \\
Hybrid & 62 & $14.4 \%$ & 211775 & $23.6 \%$ & 3415.72 \\
Shares & 76 & $17.6 \%$ & 321091 & $35.8 \%$ & 4224.89 \\
Total & 432 & & 898058 & & \\
\hline
\end{tabular}

Table 1 Number and value of European M\&A 2000-2010

(Sample of 432 transactions after exclusion of squeeze out and buyback programs of the original sample of 528 deals, 2000-2010, see annex1; values in million USD; source Thomson One Banker)

An important number of deals were private deals. Direct negotiation between the two parties converged and a block sale occurred. A total of 66 private transactions were identified, often linked to going private operations. All these private acquisition are "cash only" deals. 
The sample of targets firms shows a large number of deals targeted at British firms (43\%). Martynova and Renneboog (2009) noticed the same dominance of British firms in their sample. The transactions initiated by acquirers located in the EU represent $79 \%$ of the sample (see Table 2). Cross border deals (21\% of the total) will refer to outside EU acquirers. Table 3 analyzes the origin country of the target by means of payment. We introduce a distinction between cross border acquirers coming from the USA and acquirers coming from the rest of the world. We see that pure intra country deals are more often paid full share than full cash. Conversely, non US acquirer entering into a cross border acquisition will pay 9 times out of 10 fully in cash. However looking at initiators coming from other EU countries or from the USA, they have similar proportions of mean of payment. For instance, we cannot say that US acquirers will systematically pay in cash. They use full cash payment only 3 times out of 4 .

\begin{tabular}{lll}
\hline Target Country & Number & $\%$ \\
\hline Italy & 18 & $4.17 \%$ \\
France & 69 & $15.97 \%$ \\
UK & 186 & $43.06 \%$ \\
Netherlands & 46 & $10.65 \%$ \\
Germany & 48 & $11.11 \%$ \\
Spain & 52 & $12.04 \%$ \\
Belgium & 13 & $3.01 \%$ \\
Total & 432 & $100.00 \%$ \\
\hline (Intra EU acquirer) & $(340)$ & $(78.70 \%)$ \\
\hline
\end{tabular}

Table 2 European M\&A transactions by country of target firm (Sample of 432 transactions, period 2000-2010, target firms incorporated in Italy, France, the UK, the Netherlands, Germany, Spain and Belgium; Intra EU acquirer: Initiator incorporated in North America, Japan or other European countries; see Table 1)

\begin{tabular}{lllllllll}
\hline & Cash & $(\%)$ & Hybrid & $(\%)$ & Shares & $(\%)$ & Total & $(\%)$ \\
\hline Intra European country & 137 & $58.5 \%$ & 43 & $18.4 \%$ & 54 & $23.1 \%$ & 234 & $54.2 \%$ \\
$\begin{array}{l}\text { Intra Europe Union } \\
\begin{array}{l}\text { Cross border US } \\
\text { acquirer }\end{array}\end{array}$ & 81 & $76.4 \%$ & 8 & $7.5 \%$ & 17 & $16.0 \%$ & 106 & $24.5 \%$ \\
$\begin{array}{l}\text { Cross border non US } \\
\text { acquirer }\end{array}$ & 41 & $91.5 \%$ & 7 & $14.9 \%$ & 5 & $10.6 \%$ & 47 & $10.9 \%$ \\
\hline Total & 294 & $68.1 \%$ & 62 & $14.4 \%$ & 76 & $17.6 \%$ & 432 & $100.0 \%$ \\
\hline
\end{tabular}

Table 3 Target country and means of payment

(Number of transactions, sample of 432 European transactions, period 2000-2010, see Table 2)

We analyzed the industry sector of the acquirer and the target firm using the Thomson Financial mid code. A total of 219 deals (51\%) are within industry M\&As. 
A deal is aimed at buying a large block of stocks, generally giving the initiator majority of the equity capital. However the aim to get a controlling block should at the end take into account the percentage of share previously owned by the bidder. A toehold block may explain why the percentage of shares sought is lower, although it gives a controlling position at the end of the deal. A first feature of M\&A transactions is the percentage of shares acquired in the deal. It cumulates with the percentage of shares previously held to give the percentage of shares owned after the transaction. On average over the sample, the percentage of acquired shares is $58 \%$, the percentage sought in the deal is $63 \%$ and the percentage owned after the transaction is $73 \%$ of the capital. It means that significant toeholds exist representing on the average $15 \%$ of the capital. It is explained by the subsidiary feature of many target firms. A total of 101 targets are subsidiary (19\% of the total sample). Among the subsidiary targets sub sample, the toehold percentage is on average $45.6 \%$ (median 54.6\%) of the capital. The non subsidiary firms have an average toehold of $8.5 \%$.

In a contractual approach a deal is an agreement set on a quantity and a price. Looking at firm's acquisition, the quantity side is the percentage of shares of the target acquired in the transaction. It cumulates with shares previously held by the bidder. Looking at means of payment, the percentage of shares acquired in the deal is similar using hybrid or share payments considerations. Cash payments exhibit lower acquired percentage and lower owned percentage after the deal. This is explained mainly by private block acquisition where the average bought block represents $22 \%$ of the capital. However, in that situation, the toehold is more important and shows a significant previous investment in the target's capital (around $23 \%$ ). The cash payment in public takeover is targeted at larger acquisition of capital (average of $65 \%$ ). As a result we see that the aim of M\&A transactions is control because the final owned percentage is largely around 80 to $90 \%$ of the capital of the target firm. We separate in the cash deals those following a private acquisition mechanism and those following a public takeover bid procedure. Private deals seem to follow a rationale of control building process. The acquirer of a block takes advantage of an opportunity given by a seller even if the size of the block in itself does not give him an immediate control of the target. Many blocks are small block acquisitions (with median private acquisition of $16 \%$ of the target's capital). In the case of private deals, cumulating with previous ownership results in a final blockholding of $45 \%$ of the capital. It implies a controlling position.

Cash (of which (of which Hybrid Shares




\begin{tabular}{lllllll}
\hline & & & private) & public) & & \\
\hline $\begin{array}{l}\% \text { acq'd in the deal } \\
\text { (mean) }\end{array}$ & 56.08 & 22.20 & 64.90 & 85.66 & 77.74 \\
$\begin{array}{l}\% \text { acq'd in the deal } \\
\text { (median) }\end{array}$ & 49.97 & 15.53 & 82.58 & 100.00 & 100.00 \\
$\%$ owned after (mean) & 75.18 & 45.15 & 82.89 & 94.28 & 90.79 \\
$\%$ owned after (median) & 99.26 & 28.55 & 100.00 & 100.00 & 100.00 \\
Toehold (\%) & 19.10 & 22.95 & 17.99 & 8.63 & 13.05 \\
\hline
\end{tabular}

Table 4 Percentage of target's capital acquired in the deal and held after

(Sample of 432 European transactions; 2000-2010)

The average data in table 4 will cover very different situations particularly for cash payments where the median is lower than the mean. M\&A transactions are joint contractual agreements between the bidder and the shareholders of the target firm, which are characterized (among other variables) by the percentage of acquired shares. If the means of payment have no significant influence on the contract setting, we will get similarly distributed variables in table 4 and no significant differences in the percentage of acquired or owned capital. A t-test of average is run to check if the difference in percentages of capital acquired or owned is significant according the mean of payment. Table 5 puts into evidence different rationales. The percentages of capital got through different means of payment are significantly different. The nature of the deal is different if we consider cash payment in private or public transaction. Cash payment involves percentages of capital of the target firm significantly larger than the other means of payment. The unidimensional test shows that the choice of mean of payment interferes with one of the main terms of the contractual setting. For rational players it is a significant variable that influence the agreements. However, in any situation, the averages are not different when considering hybrid and full share payments. If we look at the targeted share of capital, there is no difference in the nature of the deal between hybrid and share payments.

\begin{tabular}{lll}
\hline Means of payment & $\%$ acq'd in the deal & $\%$ owned after \\
\hline Cash vs. share deals & 0.00 & 0.00 \\
Cash/private deals vs. & 0.00 & 0.00 \\
Cash/public deals & & \\
Cash/public vs. hybrid deals & 0.00 & 0.00 \\
Cash vs. hybrid deals & 0.00 & 0.00 \\
Hybrid vs. share deals & 0.14 & 0.32 \\
\hline
\end{tabular}

Table 5 Test of difference between the percentage of acquired and held capital after the transaction (t-test, p-values, see Table 4;) 
Looking at hybrid payments, the average percentage paid in cash is $47 \%$. The distribution of the percentage of cash is large. For instance $25 \%$ of the mixed payment deals have a cash part lower than $30 \%$ of the transaction value (see table 6 ).

\begin{tabular}{llllll}
\hline & Average & Median & 1st Quart. & 3rd Quart & $N$ \\
\hline \% paid in cash & 47,19 & 49,14 & 29,97 & 66,09 & 58 \\
\hline
\end{tabular}

Table 6 Percentage paid in cash in mixed payment transactions

(Sample of 432 European M\&A transactions)

The offer premium in percentage is another term of the transaction. On average the premium is between 17 and $28 \%$ of the target's share price 1 day before announcement. Looking at the means of payment, average paid premiums seem to be similar. Particularly, average full cash and hybrid premiums are very close. A t-test confirms the rejection of the idea of different premiums according to hybrid or full cash payments. However these results are not strong comparing shares payment premiums between with the others. Share payment premiums are different and significantly lower only at the $10 \%$ level.

\begin{tabular}{llll}
\hline Offer premium & Cash & Hybrid & Shares \\
\hline Average & 25.53 & 27.80 & 17.29 \\
Median & 17.28 & 21.99 & 12.45 \\
1st quart & 6.95 & 10.40 & 4.37 \\
3rd quart & 38.74 & 41.94 & 31.57 \\
$\mathrm{~N}$ & 217 & 49 & 55 \\
t-test & cash vs. shares & cash vs. hybrid & hybrid vs. shares \\
p-value & 0.078 & 0.574 & 0.057 \\
\hline
\end{tabular}

Table 7 offer premium by mean of payment

\subsection{Variables}

The variables are described in Table 8. Most of them are taken from the Thomson One Banker data base. A lot of variables are calculated from the previous one.

\begin{tabular}{l|l}
\hline Variables names & Description \\
\hline ACQ_CASH_HLDG & Acquirer cash and receivables as of the previous financial report (\$mil) \\
ACQ_EBITDA & Acquirer EBITDA at last financial report (\$mil) \\
ACQ_LEV & Calculated using the ratio of ACQ_NET_DEBT divided by \\
ACQ_MKT_VAL_4W & ACQ_NET_DEBT plus ACQ_NET_ASS \\
ACQ_NET_ASS & Acquirer market value of equity 4 weeks prior to announcement (\$ mil) \\
ACQ_NET_DEBT & Acquirer net assets : Total asset at last financial report minus total \\
& $\begin{array}{l}\text { liabilities }(\$ m i l) \\
\text { Acquirer Net Debt: Calculated by adding the acquirer's straight debt, } \\
\text { short-term debt, and preferred equity and subtracting cash and } \\
\text { marketable securities as of the date of the most recent financial } \\
\text { information prior to the announcement of the transaction (\$mil). }\end{array}$ \\
\hline
\end{tabular}




\begin{tabular}{|c|c|}
\hline$\overline{\text { ACQ_PC_CASH }}$ & $\begin{array}{l}\text { Acquirer ratio of cash holding (ACQ_CASH_HLDG) divided by } \\
\text { transaction value, TRANS_VAL }\end{array}$ \\
\hline ACQ_PC_EBITDA & $\begin{array}{l}\text { Acquirer ratio of EBITDA (ACQ_EBITDA) divided by transaction } \\
\text { value, TRANS_VAL }\end{array}$ \\
\hline ACQ_PC_PPE & Ratio of acquirer's ACQ_NET_DEBT compared to ACQ_PPE \\
\hline ACQ_PPE & Acquirer property, plant, equipments at LTM (\$mil) \\
\hline ACQ_Q & ACQ_MKT_VAL_4W divided by ACQ_NET_ASS \\
\hline ASYMMETRY1 & $\begin{array}{l}\text { Ratio of relative net assets: TARG_NET_ASS divided by } \\
\text { ACQ_NET_ASS }\end{array}$ \\
\hline ASYMMETRY2 & $\begin{array}{l}\text { Ratio of target market value TARG_MKT_VAL divided by acquirer } \\
\text { market value } 4 \text { week prior ACQ_MKT_VAL_4W }\end{array}$ \\
\hline ASYMMETRY3 & $\begin{array}{l}\text { Ratio of transaction value of the target compared with the accounting } \\
\text { value acquirer: TRANS_VAL divided by } \\
\text { (ACQ_NET_ASS+ACQ_NET_DEBT) }\end{array}$ \\
\hline ASYMMETRY4 & Ratio of the target'Q and the acquirer's Q: TARG_Q/ACQ_Q \\
\hline DESEQ & $\begin{array}{l}\text { Disequilibrium in the transaction setting: difference between the } \\
\text { percentage of shares sought by the acquirer and the percentage of shares } \\
\text { acquired. }\end{array}$ \\
\hline DOMESTIC_ACQ & $\begin{array}{l}\text { Dummy if the target and the acquirer are incorporated in the same } \\
\text { country }\end{array}$ \\
\hline DUM_CASH & Dummy for full cash payment \\
\hline DUM_CHALLGED_DEAL & Dummy challenged deal where a third party launched an offer \\
\hline DUM_EU_ZONE & Dummy if acquirer is incorporated in the EU (limited to 7 contries) \\
\hline DUM_HYBRID & Dummy for mixed cash-share payment transaction \\
\hline DUM_SH & Dummy for full share payment \\
\hline DUM_SUBSIDIARY & Dummy is target is a subsidiary \\
\hline DUM_TARG_FAM_OWN & $\begin{array}{l}\text { Target is family owned/controlled at the } 20 \% \text { level. This dummy is } \\
\text { indicated also if a chairman owns a substantial stake (defined as } 20 \% \text { ). }\end{array}$ \\
\hline DUM_TOE & $\begin{array}{l}\text { Dummy for toehold shares of the target held before the transaction. See } \\
\text { TOEHOLD. }\end{array}$ \\
\hline EBIT_ROA & $\begin{array}{l}\text { Target EBIT divided by Total Assets for the last } 12 \text { months ending on the } \\
\text { date of the most current financial information }\end{array}$ \\
\hline ENT_VAL & $\begin{array}{l}\text { Enterprise Value of the target calculated by multiplying the number of } \\
\text { actual target shares outstanding (from the most recent balance sheet } \\
\text { released prior to the announcement) by the offer price and then by adding } \\
\text { the cost to acquire convertible securities, plus short-term debt, straight } \\
\text { debt, and preferred equity minus cash and marketable securities, stated in } \\
\text { millions. This data item is for the enterprise value of } 100 \% \text { of the } \\
\text { company based on the offering price, regardless of how much was } \\
\text { actually acquired in the transaction. }\end{array}$ \\
\hline EQ_VAL & $\begin{array}{l}\text { Equity Value of the target calculated by multiplying the actual number of } \\
\text { target shares outstanding from its most recent balance sheet by the offer } \\
\text { price per share plus the cost to acquire convertible securities, stated in } \\
\text { millions. This data item is for the equity value of } 100 \% \text { of the company } \\
\text { based on the offering price. }\end{array}$ \\
\hline FRIEN_ATTITUD & Attitude of the board of the target company ( 0 : not friendly, 1:yes) \\
\hline OFFER_PREMIUM_1W & Same as previous but 1 week prior \\
\hline PERC_ACQ_SH_ISSU & $\begin{array}{l}\text { Percentage of acquirer's shares issued: Number of common shares issued } \\
\text { in the transaction divided by total number of acquirer's shares. }\end{array}$ \\
\hline PERC_CASH & Percentage of cash and assimilated (debt) paid in the transaction \\
\hline PERC_OWN_AFTER & Percentage of shares own after transaction \\
\hline PERC_SEEKINGG_TO_OWN & $\begin{array}{l}\text { Percentage of shares acquirer is seeking to own after the transaction. It } \\
\text { includes shares held before. }\end{array}$ \\
\hline PERC_SH & Percentage of the transaction paid by issued shares of the acquirer \\
\hline PERC_SH_ACQ & Percentage of shares acquired in transaction \\
\hline PERC_SOUGHT & Percentage of shares sought by acquirer in the transaction \\
\hline SAME_SECTOR & Dummy for same industry codes between target and acquirer. Thomson \\
\hline
\end{tabular}




\section{TARG_LEV \\ TARG_LEV1}

TARG_MKT_VAL

TARG_NET_ASS

TARG_PC_CASH

TARG_Q

TARG_Q1 mid sector codes are used.

Ratio of 1 minus EQ_VAL divided by ENT_VAL.

Target long term debt divided by total capitalization as of the date of the most current financial information. Total capitalization is long term debt plus equity.

Target Market Value: Calculated by multiplying the total number of target shares outstanding times the target stock price 4 weeks prior to announcement date (\$mil)

Target Net Assets: Total assets minus total liabilities on the date of most recent financial information (\$mil)

Ratio of target cash and receivables (TRAG_CASH_HLDG) divided by transaction value, TRANS_VAL.

Ratio of Enterprise Value to Target Capitalization: Enterprise value is calculated by multiplying the number of actual target shares outstanding by the offer price and then by adding the cost to acquire convertible securities, plus short-term debt, straight debt, and preferred equity minus cash and marketable securities. Capitalization is defined at Short-Term Debt + Long-Term Debt + Shareholder's Equity as of the date of the most current financial information prior to the announcement.

Ratio of Enterprise Value to Net Assets: Enterprise value divided by target net assets as of the date of the most current financial information. The enterprise value of a transaction is calculated by multiplying the number of target actual shares outstanding from its most recent balance sheet by the offer price and then by adding the cost to acquire convertible securities, plus short-term debt, straight debt, and preferred equity minus cash and marketable securities as of the date of the most recent financial information

Percentage of share of the target held before the transaction. Calculated using the difference between PERC_OWN_AFTER minus PERC_SH_ACQD

Value of Transaction (\$ mil): Total value of consideration paid by the

acquirer, excluding fees and expenses.

TRANS_VAL

Table 8 (LTM: Last Twelve Months: financial information is taken from the last reports prior the announcement; source: Thomson and after treatments)

The variables considered to determine the contractual setting of M\&As are those mentioned in the literature.

Financing conditions of the acquirer is a first explanation of the choice of means of payment and of the paid price. Cash capacity of the acquirer is identified with ACQ_PC_CASH and ACQ_PC_EBITDA. Raising debt is also a substitute to internal cash payment: It depends on the debt capacity of the acquiring firm. Two variables can be used to proxy it: The collateral value of his assets is ACQ_PC_PPE; it is expressed as the ratio of net debt compared to the acquirer's plant, property and equipment. A low value shows an important debt capacity based on fixed assets. The other variable is the acquirer's financial debt leverage ACQ_LEV. The idea here is simply that highly leveraged firms are more likely to choose equity financing. These variables are drawn from the financial report at the end of the year prior to the deal. Target leverage is also an element that can influence the acquirer capacity to finance the deal. 
In a situation of success, a low leveraged subsidiary with a good debt capacity will help the initiator to finance the deal using debt and cash. TARG_LEV is a variable which measure the target financial leverage. It is set as the ratio of the equity value of the target valued (using the offer price) divided by the total enterprise value of the target (with equity also taken at the offer price) minus one. This leverage is market valued. We also use TARG_LEV1 which is book valued. The cash situation of the target is also an element which is of interest because a buyer cans self pay an acquisition. We used the variable TARG_PC_CASH. A good cashflow from the target is also an element which helps to repay debt issued by the initiator when implementing the transaction. We considered the EBIT_ROA ratio

The target Tobin's Q may be proxied by the ratio of his equity valued at the offer price compared with the book value of equity at the last financial report named TARG_Q in table 8. Another proxy (labeled TARG_Q1) measures the acquirer Tobin's Q using the ratio of his market value four weeks before the transaction divide by his equity net asset amount taken from the mast financial report (ACQ_Q). The Q values measure the growth opportunities of the buyer and of the seller. It also proxies a possible market overvaluation of the acquirer's stock value.

The PERC_ACQ_SH_ISSUED variable is used as a proxy for assessing a risk on the control situation of the acquirer. As in Faccio and Masulis (2005), this variable is set using a 20\% control threshold. The control situation of family firms is acknowledged using a dummy DUM_TARG_FAM_OWN. Another dummy takes into account the subsidiary feature of the target (DUM_SUBSIDIARY)

The competitive nature of the takeover has been identified in the literature as a strong argument for cash payments. The idea is simple: cash is a signal of the will of the bidder to acquire a target and deter competition by other potential bidders (Fishman ,1989; Berkovitch and Narayanan, 1990; Cornu and Isakov, 2000) The competitive context can be measured by a dummy variable (DUM_CHALLGD_DEAL). A dummy for friendly attitude of the target is also used (FRIEN_ATTITUD).

We introduce a variable for toehold (which is set comparing the percentage of share own after the transaction and the percentage acquired through the transaction). The variable TOEHOLD 
gives the percentage of share owned before. A dummy DUM_TOE is also used when toehold exists. Toeholds may limit asymmetry of information.

The double asymmetry of information using the relative size of the target compared with the size of the bidder. A first measure of asymmetry following Hansen (1987) is the relative net asset values using book data (ASYMMETRY1). Another relative value is set comparing the transaction value spent in the transaction (TRANS_VAL) and the market value of the acquirer valued 4 weeks before (ASSYMMETRY2). The relative size is also measured comparing the total book assets (ASYMMETRY3). We may think that the Q value of each firm is also a proxy of some internal value that is not disclosed in the financial report. Each firm knows better his own growth potential. The relative size of it may be a measure of the internal private information discrepancy between the two (ASYMMETRY4).

The deal characteristics are measured using the premium (OFFER_PREMIUM_1W) or the mean of payment either in the dummy form (DUM_CASH, DUM_SH, DUM_HYBRID) or in percentage (PERC_CASH). We introduce ex ante features of the deal: PERC_SOUGHT may help in comparing if the ex post result is in linked with ex ante goals of the initiator. It compares with PERC_SH_ACQUD after the deal. The DESEQ variable measures the imbalance from the acquirer's point of view. The institutional context of the deal is acknowledged with a dummy for domestic acquisitions (DOMESTIC_ACQ) or a dummy for intra EU transactions (DUM_EU_ZONE flagging initiators that are incorporated in the EU). The TRANS_VAL value is in absolute size; it is used to see if the absolute amount of the transaction influences its outcome. The economic context of the deal and the purpose of business diversification is followed thought the dummy SAME_SECTOR.

A filtering has been applied to the asymmetry, the leverage, and the Tobin's Q variables. We eliminate the extreme values below the $1 \%$ and above the $99 \%$ of the cumulated distribution. We checked the correlation between the variables. Cross correlations between ASYMMETRY3 and TRANS_VAL, ACQ_PC_CASH and TARG_PC_CASH, ACQ_PC_CASH and ACQ_PC_EBITDA, PERC_SOUGHT and DUM_TOE, PERC_ACQ_SH_ISSU and ASYMMETRY1, PERC_ACQ_SH_ISSU and ASYMMETRY3, EBIT_ROA and ASYMMETRY4, TARGET_Q and ASYMMETRY4, ACQ_PC_CASH and TARG_LEV, TARG_Q and EBIT_ROA, PERC_ACQ and TOEHOLD are important (above 0.30). So we disregard the redundant explaining variables. 
The proxy of asymmetry of information shows that the bidder is relatively better informed than the target. However the relative Q ratio (ASYMMETRY4) is interesting in the sense that it is above 1. It should not be considered as a good measure in absolute terms because our measures of acquirer's $\mathrm{Q}$ and target's $\mathrm{Q}$ are not perfectly homogenous.

The correlation matrix among information asymmetry measures (see Annex 2) shows that the variables ASYMMETRY1, ASYMMETRY2 and ASYMMETRY3 are highly correlated .ASYMMETRY 2 is populated with a limited number of observations. It is cross correlated with ASYMMETRY3 and ACQ_LEV. We will hereafter only consider either ASYMMETRY1 or ASYMMETR3. The two variables TAR_LEV and TARG_LEV1 are perfectly correlate and redundant. We choose TARG_LEV. The two TARG_Q and TARG_Q1 measures are also highly correlated. We choose the first.

The descriptive statistics of the variable are presented in Annex 1. The Tobin's Q value of the target and the acquirer are similar (3.6 vs. 3.3). An average toehold of $14 \%$ for those firm holding shares (30\% of the sample) is evidenced. The acquirer seeks a percentage of $61 \%$ of the target's capital. He gets only $58 \%$, so a $3 \%$ disequilibrium is evidenced. Due to previous toeholds, the percentage sought after the transaction is $76 \%$ but the acquirer ends the transaction with a cumulated stake of $73 \%$. The average premium is between 25 to $30 \%$ depending if it is calculated 1 day or 4 weeks before.

\section{Empirical tests}

\subsection{Methodology and hypotheses}

According Faccio and Masulis (2005), «Since we expect both bidder and target preferences to affect the offer price and its form of consideration, we would ideally like to simultaneously estimate equations capturing the two parties' preferences. However, identification requires information about a target's stand alone value relative to its purchase price (takeover premium) as well as the form of payment. Access to information about a target's stand alone value is unavailable, given that most of these firms are privately held. This precludes estimating the alternative purchase prices conditional on form of payment. As a consequence, we have chosen to estimate a reduced form equation that includes both parties' preferences as 
explanatory variables. ». The test we implement considers the transaction characteristics as a whole. Cash payment and premiums are jointly set. We intend to set up a simultaneous equations model explaining the means of payment and the takeover premium. The same methodology was used by Officer (2003) to take into account the endogeneity between the premium and the existence of termination fee paid to the bidder. However in a first step we analyze separately the determinants of the payment decision and those of the premium.

The variable conditioning the parameters setting of the contract are mentioned in table $9 . \mathrm{We}$ considered a limited sub-sample of variable after taking into account colinearities. The expected relationship of each one versus either the percentage of cash (covering the three situations of full share/mixed/full cash payments) or the premium paid is also mentioned. We introduce a distinction between the three main explicative theories: (i) the financing decision explanation, (ii) the asymmetry of information and contractual setting approach, and (iii) the conditioning by environmental characteristics of the deal.

\begin{tabular}{|c|c|c|c|c|c|c|}
\hline \multirow{2}{*}{$\begin{array}{l}\text { Dependant variable } \\
\text { Independent }\end{array}$} & \multicolumn{3}{|c|}{ Perc cash } & \multicolumn{3}{|c|}{ Premium } \\
\hline & $\begin{array}{c}\text { Financial } \\
\text { constraint }\end{array}$ & $\begin{array}{c}\text { Contractual } \\
\& \mathrm{Al}\end{array}$ & Environment & $\begin{array}{c}\text { Financial } \\
\text { constraint }\end{array}$ & $\begin{array}{c}\text { Contractual } \\
\& A \mathrm{I}\end{array}$ & Environment \\
\hline PERC_SH_ACQD & - & & & & & \\
\hline TRANS_VAL & - & & & - & & \\
\hline SAME_SECT & & - & & & & \\
\hline DOMESTIC_ACQ & & & - & & & - \\
\hline ACQ_PC_EBITDA & + & & & & & \\
\hline TARG_PC_CASH & + & & & + & & \\
\hline FRIEN_ATTITUD & & - & - & & & - \\
\hline OFFER_PREMIUM_1W & & + & & ns & ns & ns \\
\hline DUM_TOE & & + & & & + & \\
\hline EBIT_ROA & + & & & + & & \\
\hline ACQ_LEV & - & & & & & \\
\hline TARG_LEV & - & & & & & \\
\hline ACQ_Q & - & & & + & & \\
\hline TARG_Q & & $+/-$ & & & + & \\
\hline DUM_CHALLGED_DEA & & & + & & & + \\
\hline PERC_SOUGHT & - & & & & & \\
\hline DUM_SUBSIDIARY & & + & & & + & \\
\hline ASYMMETRY1 & & - & & & - & \\
\hline DESEQ & & & & & - & \\
\hline PER_ACQ_SH_ISSU & & & + & & & \\
\hline PERC_CAS̄H & $\mathrm{ns}$ & $\mathrm{ns}$ & ns & & + & \\
\hline
\end{tabular}

Table 9 - Expected sign between the percentages paid in cash and the offer premium and possible determinants 
(According to three main theoretical approaches: Financial constraint and limitation theory, asymmetry of information and contract theory, environment and firm characteristics; AI: asymmetry of information)

The percentage of cash in a financial constraint approach is positively linked with acquirer's cash holding and Ebitda, and with the target's margin. It is negatively linked with leverage, with the absolute size of the transaction and the percentage of acquired shares. The overvaluation hypothesis introduces a negative link when the acquirer wants to time the stock market to finance the transaction. The asymmetry of information introduces a risk sharing preference. The existence of a toehold will favor share payment in the mix. The toehold is a driver to access to better information and to reduce the asymmetry problem. The bidder will pay more in shares when he enjoys better information. This is not intuitive. Same results are got with the variables used as device to reduce the asymmetry of information. The existence of toehold or the subsidiary status of a target, are viewed as a device to reduce the asymmetry and the acquirer does not need to issue shares for risk-sharing purpose. Similarly, the relationship with the absence of economic diversification is negative. The premium is linked in the contractual setting with the means of payment. At equilibrium, for hybrid payments, the acquirer may be willing to pay a slightly higher premium (i.e. to abandon a higher part of the M\&A creation of value to the seller) if he can seize a larger part of the future profits by paying by cash to avoid dilution. The target's shareholders capture the actual value of future gains by accepting more immediate cash. The environmental features are known: cross border and challenged deals are more largely paid in cash.

Looking at the premium, liquid and profitable firms can pay more. The same may be true if they have large Tobin's Q to time the market and issue largely priced shares. The asymmetry of information approach says that asymmetry of information is a risk which is balanced by lower prices and premiums. Targets which are subsidiaries, or where toehold stakes held by the acquirer exist, are more transparent to the buyer and can be paid more. The same is true if the opportunity growths of the target are large. The percentage of cash has a trade-off relationship with the premium paid. The context of the deal will also influence the paid price with an increase if it is competitive or if it is a cross border deal. Similarly for characteristics of the firms: for instance when the size of the target is large, the bidder will pay more in shares. 
The DESEQ variable takes into account a possibility that the final terms are not equilibrium terms from the buyer's point of view. It is the difference between the percentage of shares sought in the deal and the percentage effectively bought. A positive discrepancy means that, to his opinion, he should have paid more to get a higher stake of capital. So we expect a negative sign.

The acquirer's Q ratio is a double face variable: it can signal an overvalued share value and a possibility to time the market by the bidder's managers. But it may also signal good future perspectives of the firm (Martin, 1996). Former shareholders may not want to share growth opportunities with new blockholders. To avoid dilution of the former shareholder's, the payment in shares to new shareholders is voluntarily limited. Financial constraints or limitation may explain equity payment and financing: this will occur when the percentage of share acquired is important, or when the size of the deal is important.

\subsection{Determinants of the payment decision}

The mean of payment decision may be analyzed as a continuum between 0 and $100 \%$ cash payment. This approach views the determinants as playing a continuous role to explain the cash percentage. Traditionally a linear model will imply that a significant given determinant explains at the same time a full cash, a full equity or a mixed payment. The hypothesis of a unique set of determinants over the scope of cash percentage payment is very strong and questionable. The alternative hypothesis is that there are possibly three different regimes of means of payment, each one explaining either the full-cash, or the full equity or the mixed equity payment. The idea of three regimes is based on the idea that the full-equity and the full-cash payments are « corner solutions » for a rational investor (La Bruslerie, 2010). Even a methodology of Tobit regression, as the one implemented by Faccio and Masulis (2005), relies one the hypothesis of a unique set of determinants. It only takes into account the fact that the dependant variable (i.e. the percentage of cash payment) is constrained. So the distribution of errors hypothesized in a simple Probit or Logit model may be not satisfied. However a Tobit model does not allow for the possibility of different rationales in choosing the means of payment. 
In a first step we will consider globally the whole observations. The used of a Probit analysis to identify the variable influencing the decision of each mean of payment against the other two is not sound. Can we say that, when choosing a hybrid payment and rejecting full cash or full share payments, the acquirer is indifferent between the last two? We analyze pure alternative choices using a Probit analysis of a mean of payment against another one. With three means of payment, it gives three Probit analyses. Table 10 confirms that a larger offer premium increases the possibility of a hybrid or a cash payment. Asymmetry variable is not significant, but when the target is a subsidiary or when the acquirer has a toehold stake, the probability of a hybrid payment increases compared with a full share one. It means than the lower asymmetry of information linked with such a situation does not result in a risk sharing full share scheme. The presence of an important internal cash flow favors cash payment. The challenged deals are more frequently paid in cash. As Martynova and Renneboog (2009), we do not find a significant or consistent relationship between the bidder's financial condition (e.g. leverage) and the means of payment. A leveraged target makes the deal more frequently paid with shares or hybrid payments. The explanation here should be set in conjunction with the no relevance of acquirer's debt leverage. The latter has a good financial structure before the deal, and the new financial structure of the group after the merger should not be hit by a larger debt linked with cash payment. This rationale impacts the deal when it implies merging with a relatively indebted target. So the acquisition of a leveraged target is more paid with shares to limit the side effect of the acquisition on the acquirer's own leverage. This explanation goes along with dynamic debt capacity limitation which occasionally will stress the cash payment scheme.

\section{INSERT TABLE 10}

The acquirer's Q is positively linked with share payment, what is in line with the stock overvaluation explanation. It does not support the idea of privately known growth opportunities at the acquirer's level which would lead him to prefer cash payments (Martin, 1996). The target's Q ratio is significant against cash payment. Good opportunity growths at the target's level may favor full or partial payment with shares. The target's Q is significant and goes with the probability to have a full equity payment. This is in line with what was expected since the acquirer is facing an information risk about the opportunity growth of the target. A large part of the latter's value is not linked with accounted assets in the balance 
sheet. Therefore, a higher exposure to risky information on the off-balance sheet value may push the acquirer to cover that risk using share payment.

-) Robustness checks over the whole sample

We tried to use an ordered Logit model where the dependent variable equal 2 in full cash, 1 in hybrid, and 0 in full equity payment situations (as in Faccio and Masulis, 2005). We also tried to use a multinomial Logit test of the three cases in the spirit of Martynova and Renneboog (2009). However the structure of the data is not conclusive and no convergent results are obtained with the full set of explaining variables. A restricted ordered Logit model with 3 ordinal dependant variable works well with 5 dependant variables plus a constant. Four out of five are significant. However this model introduces a unique model value and uses cuts to create three classes. A restricted multinomial Logit is also run. It tests jointly the difference between all-cash and hybrid payments and the difference between cash and all-share payments. The variables are not significant in the first alternative case but are with regard to the cash/share payment alternative. We still have a probability to choose cash payment increasing with the offer premium and the target leverage and a probability of choosing share payment increasing with the information asymmetry and the transaction absolute value (see table 11). This result illustrates that full cash and full share are opposite corner solutions (Carleton et al., 1983). At the same time the variable explaining the choice between cash and hybrid payments are not the same because none of the previous ones are significant. It supports the idea that hybrid payment choice follows a different rationale and is explained by other variables. The overall regime of payment choice is a pure alternative between these two schemes.

\begin{tabular}{|c|c|c|c|c|c|}
\hline \multicolumn{3}{|l|}{ Ordered Logit } & \multicolumn{3}{|l|}{ Multinomial } \\
\hline & & & Cash vs. Hybrid & & \\
\hline Variable & Coefficient & $\mathrm{p}$-val & $\underline{\text { Variable }}$ & Coefficient & $\mathrm{p}$-val \\
\hline$\overline{\text { Constant }}$ & 1,6488 & $0,0000^{a}$ & $\overline{\text { Constant }}$ & $-0,1998$ & 0,7886 \\
\hline TRANS_VAL & 0,0000 & $0,0313^{b}$ & TRANS_VAL & 0,0000 & 0,4542 \\
\hline TARG_LEV & 1,3210 & $0,0547^{c}$ & TARG_LEV & 1,2509 & 0,5662 \\
\hline OFFER_PREMIUM_1W & 0,0101 & $0,0457^{\mathrm{b}}$ & OFFER_PREMIUM_1W & 0,0193 & 0,3102 \\
\hline ACQ_Q & 0,0292 & 0,4495 & ACQ_Q & 0,0054 & 0,9703 \\
\hline ASYM̄METRY1 & $-0,5641$ & $0,0001^{a}$ & ASYM̄METRY1 & $-0,2361$ & 0,5068 \\
\hline Cut(1) & $-0,0624$ & 0,7118 & Cash vs. Shares & & \\
\hline \multirow[t]{4}{*}{ Cut(2) } & 1,0000 & $0,0000^{\mathrm{a}}$ & Constant & 1,3898 & $0,0000^{\mathrm{a}}$ \\
\hline & & & TRANS_VAL & $-0,0001$ & $0,0812^{\mathrm{C}}$ \\
\hline & & & TARG_LEV & 1,9682 & $0,0347^{b}$ \\
\hline & & & OFFER_PREMIUM_1W & 0,0192 & $0,0075^{\mathrm{a}}$ \\
\hline
\end{tabular}




\begin{tabular}{llrr}
\hline & ACQ_Q & 0,0290 & 0,5985 \\
& ASYMMETRY1 & $-0,7349$ & $0,0002^{\mathrm{a}}$ \\
$\mathrm{N}=221$ & $\mathrm{~N}=221$ & & \\
Log Likelihood=-178.68 & Log likelihood=-176,13 & & \\
\hline
\end{tabular}

Table 11 - Determinants of ordinal choices between cash, hybrid and shares payments

(Ordered values: Cash(2), Hybrid(1), Shares(0); ordered Logit and multinomial Logit estimates; cut are estimated limits between classes; multinomial estimates of cash vs. hybrid alternate choice and cash vs. shares choice; robust covariance estimate are used to adjust for heteroscedasticity; variables definition: see Table 8; European M\&A transactions; 2000-2010; a: $1 \%$ significance level; b: $5 \%$ significance level; c: $10 \%$ significance level)

The above Logit and Probit models do not see the means of payment as a continuum but see 3 ordered classes. We now turn to the percentage of cash as dependant variable covering the continuum from 0 to $100 \%$ data. Using Tobit analysis may appear to take into account the truncated nature or the percentage of cash payment. The truncation applies if the independent variable observations are truncated for any reasons versus their real underlying values. It is not the case here where the observations are not truncated compared with the underlying phenomenon which is a percentage. Using a Tobit model as in Faccio and Masualis (2005) may explain because the limit observations of the independent variable, i.e. $0 \%$ and $100 \%$, are overrepresented in their sample. This is also the case in our sample where hybrid deals comprise only $14 \%$ of the total. The Tobit analysis of the global sample is not conclusive and the algorithm does not converge with 18 regressors (see Table 12). The significance analysis of the individual variables may be biased. We used a simple linear regression of the PERC_CASH variable to compare with. The results are similar to the Tobit's ones. The percentage of cash in payment is increasing with the offer premium. It is decreasing with the absolute size of the transaction, with the same economic sector dummy, with domestic transactions, with the leverage ratio of the target, with the subsidiary dummy. The control features are not explicitly addressed in the regressor's list because of the colinearity between ASYMMETRY1 and PERC_ACQ_SH_ISSU. We also used a modified regressors' list including the percentage of the acquirer's capital issued to pay the deal and a dummy for controlling family presence at the target's level. If the initiator's shareholders fear dilution or loose of control, they will be prone to pay more in cash if there is an important blockholder in the target's capital who may become an important blockholder in the newly merged company. The same is expected: if the percentage of shares newly issued is sensitive, acquirers will pay more in cash. The first variable has a null estimated coefficient, with a t-value equal to zero. It is not significant. The percentage of issued shares is strongly negative. It underlines a mechanical positive relationship between the size of issued share and the percentage of 
payment using shares. If the control has been threatened at the initiator's level, we would have got a positive relationship with shareholders curbing the amount of new shares and privileging cash payment. This result is not in line with Faccio and Masulis (2005) where a positive relationship between control and percentage of cash payment is documented (however only for their sub sample of European firms and only at the $10 \%$ level). They conclude that maintenance of control will bend the percentage of cash. However, this rationale is only effective if the controlling structure is weak. If it is not the case, a negative relationship may appear, as in our sample. The Faccio and Masulis' test on their global sample shows, as our' s, a significant negative sign, which is coherent with the absence of threaten on the structure of control.

\section{INSERT TABLE 12}

-) Modelling alternative cash/share payment

We used a restricted list of 8 explaining variables to explain the alternate full cash/full share payments. The asymmetry variable which fits the best is ASYMMETRY3. Both the Probit and the OLS estimates are convergent and confirm the previous results. Cash payment probability and percentage are negatively linked with the absolute transaction value, the same sector dummy, the domestic acquisition dummy and the asymmetry of information. They are positively explained by the acquirer's relative cash flow and the offer premium. The percentage of share payment increases when the target and the acquirer are in the same sector. This is consistent with the cash availability explanation and the financial limitation theory (Martin, 1996). This is also consistent with the risk diversification analysis: when the merger does not develop in a context of economics diversification, the buyer is more prone to reduce his risk by paying with shares. The asymmetry of information favors share payments. Cash payments are less probable with large sized transactions. The contractual approach of M\&A terms is supported with a significant link between cash payment and offer premium. We run a restricted Tobit model of the share/cash payment. The Tobit estimates are not convergent and we cannot statute on significancy. The asymmetry of information seems to go along with 
share payment. A Logit model fits better and will get the same results as the Probit one, except for the asymmetry variable ${ }^{5}$.

\section{INSERT 13}

The results between the two estimates according the samples of firms in tables 12 and 13 suggest that the nature of the determinants of the payment changes, particularly if we consider alternate "corner" choices, i.e. full cash or full equity payments. We also used a linear probability model instead of a Probit. The linear estimate function of the binary choice is shown in table 13. The fitted values of the Probit model and of the linear model of the dummy alternate choice between full cash and full share payments, are estimated. We calculated their respective cumulative density function. The correlation between the two is fairly good $(+0.67)^{6}$. It means that, although imperfect, a linear estimate of the binary choice is a good proxy for the Probit model ${ }^{7}$. Therefore using a linear fitted value to explain the binary choice is acceptable and allow us to use a system of two linear equations (instead of a non linear system of equation).

-) Hybrid payment choice and regimes of payments

Some determinants are specific to given means of payments. An estimate of the genuine explaining variable of the cash percentage in hybrid payments is done using a limited set of 8 variables because of the limited number of mixed payment transactions in our sub sample. It highlights that the percentage paid in cash is negatively linked with the offer premium. Other variables do not seem to influence it (see Table 14) ${ }^{8}$.

\begin{tabular}{lrr}
\hline Hybrid choice & & \\
\hline$\underline{\text { Variable }}$ & Coefficient & $\underline{p-v a l}$ \\
Constant & 51,0912 & $0,0000^{\mathrm{a}}$ \\
SAME_SECT & $-4,4922$ & 0,6156 \\
\hline
\end{tabular}

\footnotetext{
${ }^{5}$ Not reported here.

${ }^{6}$ The mean values of the two fitted cdf values using Probit and linear estimates are respectively 0,855 vs. 0,783 ; they have the same standard deviation $(0,149)$.

${ }^{7}$ OLS regression on dummies may not respect the normality condition for residuals. We checked the normality of residual s. The skewness test and the Bera-Jarque test confirm normality at the $1 \%$ level. However Kurtosis confirms normality only at the $10 \%$ level. We introduced here a linear model for the alternative cash/shares choice because it will simplify the estimate of our two equations system below.

${ }^{8}$ Considering the simple correlation values.
} 


\begin{tabular}{lrr}
\hline OFFER_PREMIUM_1W & $-0,3073$ & $0,0249^{\circ}$ \\
TOEHOLD & 0,0437 & 0,8300 \\
ACQ_Q & $-2,0908$ & 0,1970 \\
TARG_Q & 4,8004 & 0,2109 \\
DUM_CHALLGED_DEA & 2,8683 & 0,7878 \\
DESEQ & $-1,4388$ & 0,3140 \\
ASYMMETRY1 & 3,6990 & 0,2869 \\
\hline
\end{tabular}

Table 14 - Determinants of hybrid payment choices

(Dependant: percentage paid in cash in hybrid transactions; OLS estimates; robust covariance estimate are used to adjust for heteroscedasticity; variables definition: see Table 8; European M\&A transactions; 2000-2010; $\mathrm{N}=32$; a: $1 \%$ significance level; b: 5\% significance level; c: $10 \%$ significance level)

The cash-share alternative shows explaining variables different from the hybrid payment setting. The significant constant means that, on the average, a 51/49 mixed payment scheme is considered. Then an important offer premium will reduce the percentage of cash payment, and for an average premium of $25 \%$, it will result in a $43 / 57$ percent scheme. The other variables are not significant, particularly the information asymmetry variable. A same sector acquisition will be done more frequently with a full-equity payment and not in an all-cash scheme. This diversification risk sharing effect determines a corner solution with either full cash or full share payments and has no impact on the choice of hybrid schemes. A competitive bid favors cash in full payment choice but not in mixed. When looking at simple correlation, the same is true for a domestic acquisition. Transaction value impacts negatively a full-cash payment. This transaction value is not significant in hybrid payments (when analyzing simple correlations or the cash/hybrid Probit in table 10).

The conclusion we draw from the first step of the analysis is that the means of payment choice is a decision that follows different regimes (Carleton et al. 1983). In given contexts, some determinants are important to justify full cash or share payments. The previous empirics suggest that for instance cross country acquisitions and challenged deals are all or nothing conditions which trigger a full-cash payment. Another effect is less important. Full equity payments are linked with the offer premium. Sellers are paid less in price but more in hopes by accepting shares on the newly merged firms. Asymmetry of information and risk sharing goal will explain equity payments. These two regimes of payment are «corner solutions ». Hybrid payment introduces a continuum between the last two. They develop a complex scheme with a fine tuning of the many equilibrium variables shared in the agreement. The two most important are the price and the relative mix of payment. Hence this variable is endogenous and should be modelized specifically. 
In the previous tests, cash payment and offer premiums are endogenous. These decisions are coincidental in a contractual approach. They cannot be separated when analyzing M\&A transactions. This point is not systematically mentioned in the literature, except Faccio and Masulis (2005). It is more scarcely implemented in empirical test. It implies that the conclusion we derived in the first step of the analysis are questionable and they should be confirmed in a larger model of the transactions characteristics.

\subsection{Offer premium}

The offer premium is the well known term describing M\&A deals. Its determinants are explored in table 15 . We used a first set of 22 regressors including a constant and dummies for means of payment. The latter are not significant. The premium is increasing with the percentage of share acquired by the bidder. Challenged targets are paid more. We reduced the list of regressors to alternatives subsets of 10 or 6 variables, without any constant.

\section{INSERT TABLE 15}

The size of the offer premium is still increasing with the percentage of share acquired and when the deal is challenged. The percentage of cash payment is significant, meaning that higher cash payments lead to higher premiums. The contractual nature of a transaction appears with asymmetry of information: a large bidder relatively to the target will pay a lower premium. He can enjoy information superiority and influence the target to accept a lower premium. The target's $Q$ is positively linked with the premium. Opportunity growth at the target level enhances the paid premium. The negative EU zone dummy means that intra European firms will pay less. It evidences the empirical fact that cross border (i.e. outside Europe initiators) acquisition will pay higher premiums. The absolute size of the transaction does not influence significantly the premium.

The DESEQ variable is the difference between the percentage of shares sought by the acquirer and the effective number of acquired shares. It is a proxy of disequilibrium in the transaction between the terms offered by the bidder and the strength of the agreement by the seller. For instance, tight conditions will result in a high value of DESEQ. The negative sign associated with that variable shows a link with relatively low (and insufficient) premiums. We 
will use thereafter the linear equations to model the offer premium either in a large definition with 10 independent variables (equation Premium) or a restricted list of 6 variables (equation Premium1).

\subsection{Simultaneous equations}

As far as premiums and means of payment are jointly set we have to use simultaneous equations (Betton and Eckbo, 2000; Officer, 2003). We distinguish two models to asses the regimes of payment. In each situation there is an endogenous link between the terms of the transactions. We first tested a unique system for the global cash/mixed/shares sample. It will be used as a benchmark before specific regimes system estimates. We acknowledge that it ignores the existence of two regimes in the mean of payment choice. We first check a large system version:

OFFER_PREMIUM_1W $=\mathrm{a}_{1} *$ PERC_SH_ACQD $+\mathrm{a}_{2} *$ PERC_CASH $+\mathrm{a}_{3} *$ DESEQ + $\mathrm{a}_{4} *$ TARG_Q+ $\mathrm{a}_{5} *$ DUM_CHALLGED_DEA $+\mathrm{a}_{6} *$ ASYMMETRY $1+\mathrm{a}_{7} *$ TRANS_VAL + $\mathrm{a}_{8} *$ SAME_SECT $+\mathrm{a}_{9} *$ DUM_EU_ZONE $+\mathrm{a}_{10} *$ DUM_SUBSIDIARY

PERC_CASH $=b_{0}+b_{1} *$ TRANS_VAL $+b_{2} *$ SAME_SECT $+b_{3} *$ DOMESTIC_ACQ + $\mathrm{b}_{4} *$ ACQ_PC_EBITDA + $\mathrm{b}_{5} *$ OFFER_PREMIUM_1W $+\mathrm{b}_{6} *$ TOEHOLD + $\mathrm{b}_{7} *$ TARG_LEV + $\mathrm{b}_{8} *$ DUM_CHALLGED_DEA $+\mathrm{b}_{9} *$ DUM_SUBSIDIARY $+\mathrm{b}_{10} *$ ASYMMETRY 1

A reduced version is also tested with a more limited number of regressors:

OFFER_PREMIUM_1W $=\mathrm{a}_{1} *$ PERC_SH_ACQD $+\mathrm{a}_{2} *$ PERC_CASH $+\mathrm{a}_{3} *$ DESEQ + $\mathrm{a}_{4} *$ TARG_Q+ $\mathrm{a}_{5} *$ DUM_CHALLGED_DEA $+\mathrm{a}_{6} *$ ASYMMETRY 1

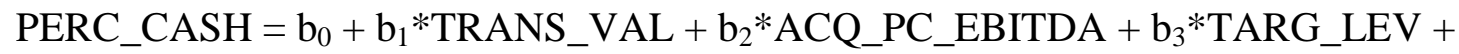
$\mathrm{b}_{4} *$ OFFER_PREMIUM_1W $+\mathrm{b}_{5} *$ ASYMMETRY1 $+\mathrm{b}_{6} *$ DUM_CHALLGED_DEA + $\mathrm{b}_{7} *$ TOEHOLD

In each equation of the system, the dependent variable of one equation is an independent variable of the other. The results are displayed in table 16. A positive relationship between the cash percentage and the offer premium is significantly evidenced in the four equations. The offer premium is positively linked with the percentage of shares acquired, the target' $Q$ and the competitive nature of the deal and negatively with the disequilibrium. This confirms the univariate premiums estimate. The percentage of cash from $0 \%$ to $100 \%$, including the two border limits, is positively influenced by TRANS_VAL, TARG_LEV, TOEHOLD and the 
dummy DOMESTIC_ACQ. This is in line with what was expected. However the information asymmetry variable is nowhere significant, contrarily to expectations.

\section{INSERT TABLE 16}

We turn to systems of equations based on different regimes of means of payment. We still have as dependant variables in each couple of equations, the offer premium and the percentage of payment. In the cash/shares regime, the dependant is a dummy for either full $\operatorname{cash}(1)$ or full share(0) payments, in the mixed payment regime the dependant variable is the percentage paid in cash.

-Cash/shares system of equations

The first system of simultaneous equations has a binary choice as endogenous variable for payment. It is a dummy variable representing the percentage of cash payment for full cash (i.e. $100 \%$ ) and full equity (0\%). Here the sample is limited to full cash or full share transactions. The difficulty is that premium is a continuous variable and the cash payment is a discontinuous variable. As mentioned by Officer (2003) we cannot use a direct standard linear approach in such a situation. We substitute the mean of payment equation using a linear continuous proxy identified in Table 13. The probability to have full cash or full share payment is fitted by a linear form instead of a Probit equation ${ }^{9}$. We estimate systems of linear equations.

OFFER_PREMIUM_1W $=\mathrm{a}_{1} *$ PERC_SH_ACQD $+\mathrm{a}_{2} *$ PERC_CASH $+\mathrm{a}_{3} *$ DESEQ + $a_{4} *$ TARG_Q $+a_{5} *$ DUM_CHALLGED_DEA $+a_{6} *$ ASYMMETRY $1+a_{7} *$ TRANS_VAL + $\mathrm{a}_{8} *$ SAME_SECT $+\mathrm{a}_{9} *$ DUM_EU_ZONE $+\mathrm{a}_{10} *$ DUM_SUBSIDIARY

PERC_CASH $=b_{0}+b_{1} *$ TRANS_VAL $+b_{2} * S A M E \_S E C T+b_{3} *$ DOMESTIC_ACQ + $\mathrm{b}_{4} *$ ACQ_PC_EBITDA + $\mathrm{b}_{5} *$ OFFER_PREMIUM_1W + $\mathrm{b}_{6} *$ TARG_LEV + $\mathrm{b}_{7} *$ DUM_CHALLGED_DEA $+\mathrm{b}_{8} *$ ASYMMETRY3

\footnotetext{
${ }^{9}$ A non linear Probit model would have been better. However it has a non linear form and lead to a non linear equations system. We tried to implement it and we get poor results. Our non linear system of equation econometric algorithms estimates coefficient assuming non zero second order derivatives. This is not the case with a Probit equation. So the standard deviations of estimates are not relevant and we cannot asses the significance of the estimated coefficients.
} 
Equation (3a) is similar to equation (1a). A more limited system is also estimated with 6 explaining variables for the offer premium instead of 10 .

OFFER_PREMIUM_1W $=\mathrm{a}_{1} *$ PERC_SH_ACQD $+\mathrm{a}_{2} *$ PERC_CASH $+\mathrm{a}_{3} *$ DESEQ + $\mathrm{a}_{4} *$ TARG_Q+ $\mathrm{a}_{5} *$ DUM_CHALLGED_DEA $+\mathrm{a}_{6} *$ ASYMMETRY1

PERC_CASH $=b_{0}+b_{1} *$ TRANS_VAL $+b_{2} *$ SAME_SECT $+b_{3} *$ DOMESTIC_ACQ + $\mathrm{b}_{4} *$ ACQ_PC_EBITDA $+\mathrm{b}_{5} *$ OFFER_PREMIUM_1W + $\mathrm{b}_{6} *$ TARG_LEV + $\mathrm{b}_{7} *$ DUM_CHALLGED_DEA $+\mathrm{b}_{8} *$ ASYMMETRY3

The estimates of the linear systems (3a-b) and (4a-b) are shown in table 18. A strong and positive relation is identified between the offer premium and the dummy cash/share. The percentage of acquired shares and the target's $Q$ are increasing with the premium. The disequilibrium variable is negatively significant. The same is true for the dummy EURO_ZONE which means that acquirer's incorporated in the EU will pay a lower premium than overseas acquirers. The determinants of the cash/share payment alternative are those previously identified (absolute size of transaction, sector diversification, dummy for domestic deals). What is new compared with the global sample test is now that the information asymmetry variable is strongly significant as expected by the risk sharing theory: The shares payment probability increases with the ASYMMETRY3 variable.

\section{INSERT TABLE 17}

The simultaneous equation test yields a more sophisticated view than a simple equation setting. The latter explains a dependant variable assuming no endogeneity in the regressors. Here a joint setting exists between the premium and the mode of payment (either all cash or all shares). The cross relation is positive and significant: premiums are higher with cash payments. Full cash offer will pay premium increased by $20 \%$ compared with shares payment. Compared to the single equation test, the difference is that the challenged characteristic of the deal is no more significant in explaining the premium. Intra EU transaction deals will have premiums with a $9 \%$ discount compared to cross border deals. Elements of the financial structure of the bidder (cash-flows and debt) have no influence on the premium paid. The financing decision is not relevant to infer the mean of payment choice (similarly to Martynova and Renneboog, 2009). The cash/share payment is a regime imposed by cross countries acquisitions, by the economic nature of the acquisition: same sector bids are more largely paid by shares. The absence of economic diversification will result in more risky synergies or 
gains. It pushes the acquirer to cover this economic risk by paying more with shares. At the end, asymmetries of information are the driving variable behind the joint choice of the premium paid and the means of payment choice.

In a binary choice between alternate means of payment it is rather difficult to find a more finely tuned agreement. The bidder can only signal the future value through the premium paid. As a result the transaction recorded is agreed but may present some disequilibrium features. Here the DESEQ variable is negative and significant. It signals that some bidders would have desired to get more shares than they effectively got. The explanation for the imbalance is simple: they do not pay enough and the premium offered was too small.

\section{- Hybrid payment system}

The second system of equation has the percentage of cash payment as dependant variable. It is estimated only on the sample of hybrid payment transactions. The major drawback of the estimation is the low number of available observations $(\mathrm{N}=32)$. We have two systems of equations according to the number of independent variables used in the offer premium equation: 10 or 6 .

OFFER_PREMIUM_1W $=\mathrm{a}_{1} *$ PERC_SH_ACQD $+\mathrm{a}_{2} *$ PERC_CASH $+\mathrm{a}_{3} *$ DESEQ + $\mathrm{a}_{4} *$ TARG_Q+ $\mathrm{a}_{5} *$ DUM_CHALLGED_DEA $+\mathrm{a}_{6} *$ ASYMMETRY $1+\mathrm{a}_{7} *$ TRANS_VAL + $\mathrm{a}_{8} *$ SAME_SECT $+\mathrm{a}_{9} *$ DUM_EU_ZONE $+\mathrm{a}_{10} *$ DUM_SUBSIDIARY

PERC_CASH $=b_{0}+b_{1} *$ SAME_SECT $+b_{2} *$ OFFER_PREMIUM_1 $\mathrm{W}+b_{3} *$ TOEHOLD + $\mathrm{b}_{4} *$ ACQ_Q $+\mathrm{b}_{5} *$ TARG_Q $+\mathrm{b}_{6}{ }^{*}$ DUM_CHALLGED_DEA $+\mathrm{b}_{7} *$ DESEQ + $\mathrm{b}_{8} *$ ASYMMETRY1

Equation (5a) for offer premium is similar to equation (3a). A more limited system is also estimated:

OFFER_PREMIUM_1W $=\mathrm{a}_{1} *$ PERC_SH_ACQD $+\mathrm{a}_{2} *$ PERC_CASH $+\mathrm{a}_{3} *$ DESEQ + $\mathrm{a}_{4} *$ TARG_Q+ $\mathrm{a}_{5} *$ DUM_CHALLGED_DEA + $\mathrm{a}_{6} *$ ASYMMETRY1

PERC_CASH $=b_{0}+b_{1} *$ TRANS_VAL $+b_{2} *$ SAME_SECT $+b_{3} *$ DOMESTIC_ACQ + $\mathrm{b}_{4} *$ ACQ_PC_EBITDA $+\mathrm{b}_{5}{ }^{*}$ OFFER_PREMIUM_1W $+\mathrm{b}_{6} *$ TARG_LEV + $\mathrm{b}_{7} *$ DUM_CHALLGED_DEA $+\mathrm{b}_{8} *$ ASYMMETRY 1 
These linear systems estimates are shown in table 18 . We do not identify a positive cross relationship between the offer premium and the percentage paid in cash in mixed payment schemes. The offer premiums are positively influenced by the size of the block of acquired shares, by the challenging status of the deal and by the target's Q value. The latter underlines the importance of growth opportunities at the target's level. A new variable appears positively linked with the premium in hybrid payments: the absolute size of the transaction (only at the $10 \%$ level). This determinant is not found significant in the full cash/full share transactions. The percentage of cash in the payment does not depend significantly on any variables. The result of our estimate on the hybrid sample is poor. The low number of observations and the large number of independent variable reduces the probability of a variable to appear as significant. Particularly the asymmetry of information is not found significant.

\section{INSERT TABLE 18}

We tried to limit the number of variable to increase the number of degree of freedom. In the panel $\mathrm{C}$ of table 18 we reduced the number of regressors. The sample is now 51 observations. We then get an offer premium positively correlated with PERC_SH_ACQ, TARG_Q and DUM_CHALLGED_DEA. The percentage of cash is now positively linked with the offer premium, highlighting a contractual trade-off. The economic diversification also influences the deal in line with the contractual approach. The sign of the acquirer's cash flow variable shows that the financial situation of the acquirers also conditions the setting of the mix of payment in the expected way. However, when looking at panel $\mathrm{C}$ the quality of the cash percentage equation remains very poor. ${ }^{10}$

How to interpret the absence of significant relationship in the case of hybrid M\&A? We already mentioned the small size of the hybrid sample. Moreover, the simultaneous equation system underlines a complex equilibrium where many variables are endogenous. The one equation test of the cash percentage evidenced negative (non significant) relationship with the asymmetry of information (see table 12; also not significant in the global sample test, see table 16). The sign of the variable turns positive and remains not significant in the hybrid system of equations. It stays negative and becomes highly significant to explain the choice of payment in the alternative cash/share sample (See table 18). We conjecture that the

\footnotetext{
${ }^{10}$ If we introduce a constant in the cash percentage equation, the independent variables turn insignificant in panel C.
} 
asymmetry of information is lower in hybrid payment schemes because of delivered information through the judicious setting of the percentage paid in cash as suggested in La Bruslerie (2010). The sample is a cross section of successful acquisitions with conditions apparently satisfying for the parties. An imbalanced situation where the bidder does not get what he wants does not appear significant and does not evidence poor premium setting. This is a strong difference with the test for alternative cash/share payments.

The hybrid payment allows a fine tuning where the characteristics of the transaction are more inflated with information. Even if a negotiation does not exist formally in a takeover bid, when using a mixed scheme of payment the bidder should integrate not only his interest but also the seller's ones. He knows that the percentage of cash is screened by the seller. We draw the conclusion that the transaction terms, particularly the percentage paid in cash, reflect equilibrium in risk sharing about the future uncertain value of the acquisition.

\section{Conclusion}

The analysis of the offer premiums and of the means of payment should not be done separately. We show that these two variables are jointly set up in a contractual approach. More precisely the relationship of cash means of payment with the offer premium is positive: higher premiums will yield mixed payment with larger cash. A trade-off equilibrium develops: when the seller wants to be paid more, he should accept to be paid more in hope (i.e. in new equity shares). The risk sharing nature of a M\&A deal is confirmed and influences the means of payment. The double risk situation relies on a double asymmetry of information between the buyer and the seller as identified by Hansen (1987). The choice of means of payment is a complex decision which can be done in alternate terms of full cash or full share payments. Hybrid payments follow a different rationale. The fine tuning of the percentage paid in cash is also an important term in a successful transaction and helps in delivering information.

Considering a sample of European M\&As over the 2000-2010 decade, the determinants of the mean of payment choice are known and confirmed. Firms with a high growth potential and a high stock value may be more prone to finance acquisition with equity. Financial conditions are poorly significant as in Martynova and Renneboog (2009). As a result we show that 
empirical analysis should not be done on global sample mixing any regime of payment. Full cash and full share payments are corner solutions which will yield different levels of equilibrium between parties. The determinants of the transaction terms are not the same and we identified two regimes of payment. Blending all the deals in one sample will assume that a continuum exists from full cash to all shares payments. Running regressions even through a simultaneous setting on a global sample can be misleading. It will ignore the difference of regimes of payments and the results may be spurious. The existence of regimes of payment in M\&A transactions is the first conclusion. We tested the different sets of determinants of M\&A terms in a contractual approach where the offer premium and the means of payment are jointly set. The underlying rationale of asymmetry of information and risk sharing calculus explains the contractual approach. It is supported by the data. It combines well with know factors such as cross border acquisitions, competitive transaction or the absolute size of the target, all of them favoring cash payment. However, the limited number of hybrid deals in our sample would justify further development. 


\begin{tabular}{|c|c|c|c|c|c|}
\hline Series & Obs & Mean & Std.Err & Minimum & Maximum \\
\hline$\overline{A C Q}$ ACASH_HLDG & 417 & 4268,3931 & 47547,7185 & 0,0060 & 966677,8710 \\
\hline ACQ_EBITDA & 422 & 4361,2206 & 35518,5197 & $-686,9000$ & 707896,9590 \\
\hline ACQ_LEV & 413 & 0,2755 & 1,7507 & $-7,2377$ & 31,6685 \\
\hline ACQ_MKT_VAL_4W & 306 & 16992,8120 & 35820,3673 & 7,3350 & 446828,4730 \\
\hline ACQ_NET_ASS & 424 & 18910,2834 & 202762,2048 & $-1021,5450$ & 4104939,1990 \\
\hline ACQ_NET_DEBT & 423 & 3555,8100 & 57384,7745 & $-959364,8320$ & 597080,3370 \\
\hline ACQ_PC_CASH & 417 & 11,8988 & 73,8880 & 0,0001 & 1015,2740 \\
\hline ACQ_PC_EBITDA & 422 & 14,3714 & 128,3267 & $-8,0298$ & 2460,0518 \\
\hline ACQ_PC_PPE & 412 & 0,5799 & 3,1177 & $-22,5154$ & 15,3450 \\
\hline$A C Q \_P P E$ & 423 & 12954,4591 & 100989,2728 & 0,2520 & 1911625,9020 \\
\hline ACQ_Q & 275 & 3,6032 & 5,0729 & $-8,2937$ & 43,8388 \\
\hline ASYMMETRY1 & 410 & 0,6592 & 1,2935 & $-0,3266$ & 10,3594 \\
\hline ASYMMETRY2 & 296 & 0,4530 & 0,7103 & 0,0009 & 4,3558 \\
\hline ASYMMETRY3 & 413 & 0,9617 & 2,8396 & $-10,5519$ & 31,0473 \\
\hline ASYMMETRY4 & 268 & 2,5601 & 8,7223 & $-0,0083$ & 99,6373 \\
\hline DESEQ & 479 & 1,8823 & 7,3729 & $-51,7620$ & 65,4400 \\
\hline DOMESTIC_ACQ & 528 & 0,6042 & 0,4895 & 0,0000 & 1,0000 \\
\hline DUM_CASH & 528 & 0,5568 & 0,4972 & 0,0000 & 1,0000 \\
\hline DUM_CHALLGED_DEA & 528 & 0,0606 & 0,2388 & 0,0000 & 1,0000 \\
\hline DUM_EU_ZONE & 528 & 0,6439 & 0,4793 & 0,0000 & 1,0000 \\
\hline DUM_HȲB̄RID & 528 & 0,1174 & 0,3222 & 0,0000 & 1,0000 \\
\hline DUM_SH & 528 & 0,1439 & 0,3514 & 0,0000 & 1,0000 \\
\hline DUM_SUBSIDIARY & 528 & 0,1913 & 0,3937 & 0,0000 & 1,0000 \\
\hline DUM_TARG_FAM_OWN & 528 & 0,0019 & 0,0435 & 0,0000 & 1,0000 \\
\hline DUM_TOE & 528 & 0,3011 & 0,4592 & 0,0000 & 1,0000 \\
\hline EBIT_ROA & 418 & 0,0914 & 0,0871 & 0,0020 & 1,0070 \\
\hline ENT_VAL & 503 & 7745,4877 & 25648,6558 & 13,0360 & 442807,6090 \\
\hline EQ_VAL & 504 & 6432,4035 & 23458,5490 & 52,0780 & 432124,5420 \\
\hline FRIEN_ATTITUD & 528 & 0,6742 & 0,4691 & 0,0000 & 1,0000 \\
\hline OFFER_PREMIUM_1W & 423 & 28,7704 & 40,9218 & $-99,2400$ & 340,4400 \\
\hline PERC_ACQ_SH_ISSU & 528 & 6,2662 & 14,8454 & 0,0000 & 96,9700 \\
\hline PERC_CASH & 417 & 92,4949 & 20,1322 & 1,2390 & 100,0000 \\
\hline PERC_OWN_AFTER & 487 & 73,1246 & 36,3815 & 0,2990 & 100,0000 \\
\hline PERC_SH & 141 & 80,6033 & 26,9872 & 13,0800 & 100,0000 \\
\hline PERC_SH_ACQD & 483 & 58,0259 & 39,7593 & 0,2620 & 100,0000 \\
\hline PERC_SOUGHT & 500 & 61,1850 & 39,7712 & 0,2940 & 100,0000 \\
\hline SAME_SECT & 528 & 0,5814 & 0,4938 & 0,0000 & 1,0000 \\
\hline TARG_LEV & 491 & 0,0946 & 0,2311 & $-0,8834$ & 0,6701 \\
\hline TARG_LEV1 & 427 & 0,2649 & 0,2028 & 0,0010 & 0,8950 \\
\hline TARG_MKT_VAL & 521 & 3953,4782 & 10549,1174 & $-42,7050$ & 113064,3820 \\
\hline TARG_NET_ASS & 520 & 2332,6581 & 6395,0014 & $-5520,8350$ & 91946,0490 \\
\hline TARG_PC_CASH & 513 & 1,2113 & 6,0299 & 0,0001 & 93,9707 \\
\hline TARG_Q & 485 & 3,2921 & 4,2978 & 0,3750 & 34,6180 \\
\hline TARG_Q1 & 478 & 4,8783 & 5,9806 & 0,4460 & 46,3910 \\
\hline TOEHOLD & 528 & 14,1002 & 26,9098 & 0,0000 & 99,4570 \\
\hline TRANS_VAL & 528 & 1804,0272 & 6586,9736 & 50,2420 & 75960,8470 \\
\hline
\end{tabular}

Annex 1 Descriptive statistics of the variables

(after filtering variables; observations above the 99\% and below the 1\% distribution eliminated for the ASSYMMETRY, TARG_Q, ACQ_G, ACQ_LEV and TARG_LEV variables, variable definitions, see table 8) 


\begin{tabular}{|c|c|c|c|c|c|c|c|c|c|c|}
\hline & ASYMMETRY1 & ASYMMETRY2 & ASYMMETRY3 & ASYMMETRY4 & $A C Q \_L E V$ & TARG_LEV & TARG_LEV1 & TARG_Q1 & TARG_Q & $\overline{A C Q} Q$ \\
\hline ASYMMETRY1 & 1,0000 & & & & & & & & & \\
\hline ASYMMETRY2 & 0,6402 & 1,0000 & & & & & & & & \\
\hline ASYMMETRY3 & 0,5914 & 0,2455 & 1,0000 & & & & & & & \\
\hline ASYMMETRY4 & $-0,0918$ & 0,0075 & $-0,0750$ & 1,0000 & & & & & & \\
\hline ACQ_LEV & 0,0620 & 0,0207 & $-0,2532$ & $-0,0171$ & 1,0000 & & & & & \\
\hline TARG_LEV & 0,1963 & 0,3240 & 0,0080 & $-0,0803$ & 0,0307 & 1,0000 & & & & \\
\hline TARG_LEV1 & 0,2494 & 0,3644 & 0,0298 & $-0,0524$ & 0,0745 & 0,5942 & 1,0000 & & & \\
\hline TARG_Q1 & $-0,0815$ & $-0,0862$ & 0,0598 & $-0,0077$ & 0,0189 & 0,0452 & 0,2777 & 1,0000 & & \\
\hline TARG_Q & $-0,1014$ & $-0,1790$ & 0,1433 & 0,0266 & 0,0191 & $-0,2035$ & $-0,1113$ & 0,6944 & 1,0000 & \\
\hline$A C Q \_\bar{Q}$ & 0,2064 & $-0,1218$ & 0,3245 & $-0,1419$ & 0,0715 & $-0,0958$ & $-0,0966$ & 0,1413 & 0,2906 & 1,0000 \\
\hline ACQ_PC_PPE & 0,0142 & $-0,0550$ & $-0,0981$ & $-0,0031$ & 0,3835 & $-0,0217$ & 0,0052 & $-0,0493$ & $-0,0714$ & 0,0327 \\
\hline
\end{tabular}

Annex 2 Correlation matrix between asymmetry of information, leverage and Tobin's $Q$ variables

(ASSYMETRY1: Ratio of target and acquirer's net assets using accounting value; ASYMMETRY2: ratio o target market value divided by the acquirer market value 4 weeks before transaction; ASYMMETRY3: Ratio of the transaction value divided by the acquirer's accounting total value; ASYMMETRY4: Ratio of the target's Q value divided by the acquirer's Q; ACQ_LEV: Ratio of the acquirer's net debt to the sum of his net book value and his net debt; TARG_LEV: One minus the equity book value divide by the enterprise total value; TARG_LEV1 Target long term debt divided by long term debt plus equity using accounting values; TARG_Q1: Ratio of Enterprise Value to Net Assets; TARG_Q:. Ratio of Enterprise Value to Target Capitalization; ACQ_Q: Acquirer's market value 4 week before transaction divide by his net asset value; ACQ_PC_PPE: Ratio of acquirer's net debt compared to his book value of properties, plant and equipments) 


\begin{tabular}{|c|c|c|c|c|c|c|c|c|}
\hline Hybrid (vs Shares) & & & Cash(vs Hybrid) & & & Cash(vs shares) & & \\
\hline Variable & Coefficient & $p$-val & Variable & Coefficient & $p$-val & Variable & Coefficient & $p$-val \\
\hline Constant & $-22,2048$ & $0,0800^{\mathrm{C}}$ & Constant & 2,8109 & $0,0882^{\mathrm{c}}$ & Constant & 5,6542 & $0,0001^{a}$ \\
\hline PERC_SH_ACQD & 0,1946 & 0,1105 & PERC_SH_ACQD & $-0,1394$ & $0,0949^{c}$ & PERC_SH_ACQD & 0,0139 & 0,7239 \\
\hline TRANS_VAL & $-0,0001$ & 0,3734 & TRANS_VAL & 0,0000 & 0,3166 & TRANS_VAL & $-0,0001$ & $0,0502^{c}$ \\
\hline SAME_SECT & $-0,1866$ & 0,7943 & SAME_SECT & $-0,2052$ & 0,5513 & SAME_SECT & $-1,3944$ & $0,0012^{\mathrm{b}}$ \\
\hline DOMESTIC ACQ & $-1,4828$ & 0,3293 & DOMESTIC ACQ & $-0,8200$ & 0,0317 & DOMESTIC ACQ & $-1,9726$ & $0,0003^{a}$ \\
\hline ACQ_PC_EBITDA & 0,8945 & 0,4544 & ACQ_PC_EBITDA & 0,3827 & $0,0490^{\mathrm{b}}$ & ACQ_PC_EBITDA & 0,0789 & 0,3920 \\
\hline TARG_PC_CASH & $-3,1509$ & 0,2592 & TARG_PC_CASH & 0,7372 & 0,6882 & TARG_PC_CASH & $-0,0108$ & 0,7447 \\
\hline FRIEN_ATTITUD & 1,8546 & 0,1231 & FRIEN_ATTTITUD & 0,6267 & 0,2897 & FRIEN_ATTITUD & 1,0383 & $0,0765^{c}$ \\
\hline OFFER_PREMIUM_1W & 0,0556 & $0,0255^{\mathrm{b}}$ & OFFER_PREMIUM_1W & 0,0102 & 0,1122 & OFFER_PREMIUM_1W & 0,0328 & $0,0003^{a}$ \\
\hline DUM_TOE & 13,0029 & $0,0896^{\mathrm{c}}$ & DUM_TOE & $-0,3448$ & 0,6447 & DUM_TOE & 0,0990 & 0,8498 \\
\hline EBIT_ROA & $-2,7898$ & 0,5621 & EBIT_ROA & $-0,5510$ & 0,9076 & EBIT_ROA & $-3,8303$ & 0,1185 \\
\hline$A C Q-Q^{-}$EV & 1,8367 & $0,0277^{b}$ & $A C Q$ LEV & $-0,0018$ & 0,9902 & ACQ LEV & $-0,1373$ & 0,5536 \\
\hline TARG'_LEV & $-9,6022$ & $0,0067^{\mathrm{a}}$ & TARG__LEV & 0,6923 & 0,5723 & TARG_LEV & $-4,8995$ & $0,0036^{a}$ \\
\hline$A C Q \_\bar{Q}$ & $-0,1631$ & 0,3295 & $A C Q \_\bar{Q}$ & 0,0748 & 0,1580 & $A C Q \_\bar{Q}$ & $-0,1164$ & $0,0377^{\mathrm{b}}$ \\
\hline TARG $Q$ & $-0,5685$ & $0,0119^{b}$ & TARG_Q & 0,3353 & $0,0557^{\mathrm{C}}$ & TARG_Q & $-0,1802$ & $0,0087^{a}$ \\
\hline DUM $\bar{C}$ HALLGED DEA & 17,2773 & $0,0079^{a}$ & DUM $\bar{C} H A L L G E D$ DEA & $-0,5239$ & 0,2823 & DUM $\bar{C}$ HALLGED DEA & 7,7897 & $0,0001^{a}$ \\
\hline PERC_SOUGHT & 0,0521 & 0,4737 & PERC_SOUGHT & 0,0997 & 0,2040 & PERC_SOUGHT & $-0,0352$ & 0,3689 \\
\hline DUM_SUBSIDIARY & 3,5970 & $0,0137^{b}$ & DUM_SUBSIDIARY & $-0,5314$ & 0,4415 & DUM_SUBSIDIARY & 0,1833 & 0,8201 \\
\hline $\begin{array}{l}\text { ASYMMETRY1 } \\
\mathrm{N}=50\end{array}$ & $-0,0859$ & 0,7589 & $\begin{array}{l}\text { ASYMMETRY1 } \\
\mathrm{N}=138\end{array}$ & $-0,2211$ & 0,2821 & $\begin{array}{l}\text { ASYMMETRY1 } \\
\mathrm{N}=132\end{array}$ & $-0,2415$ & 0,2537 \\
\hline
\end{tabular}

Table 10 Determinants of alternate choice of a mean of payment

(Probability to choose one mean of payment against another specified one, Probit estimates; Cash: full cash payment; Hybrid: mixed payment; Shares: full share payment; robust covariance estimate are used to adjust for heteroscedasticity; variable definitions: see Table 8; European M\&A transactions; 2000-2010; a: $1 \%$ significance level; b: 5\% significance level; c: $10 \%$ significance level) 


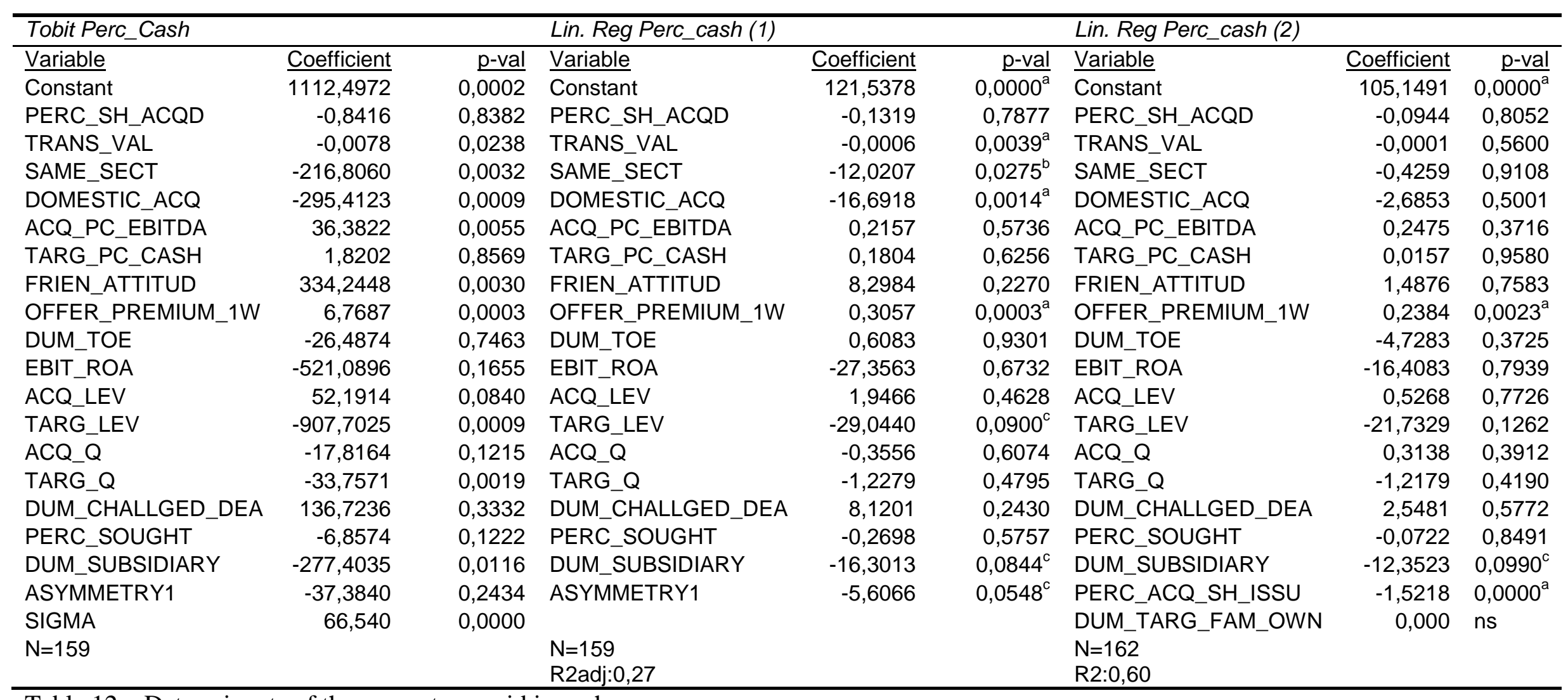

Table 12 - Determinants of the percentage paid in cash

(Dependant variable is the percentage paid in cash from 0 to 100\%; Trobit truncated estimates not convergent, p-val are not reliable; Lin.Reg.: OLS Linear estimates; ns: p-val is not significant; robust covariance estimate are used to adjust for heteroscedasticity; variable definitions: see Table 8; European M\&A transactions; 2000-2010; a: 1\% significance level; b: 5\% significance level; c: 10\% significance level) 


\begin{tabular}{|c|c|c|c|c|c|}
\hline \multicolumn{3}{|c|}{ Restricted cash/share alternative Probit } & \multicolumn{3}{|c|}{ Dummy cash/shares Linear OLS estimate } \\
\hline Variable & Coefficient & $p$-val & Variable & Coefficient & $p$-val \\
\hline$\overline{\text { Constant }}$ & 0,8768 & $0,0001^{a}$ & $\overline{\text { Constant }}$ & 0,8946 & $0,0000^{a}$ \\
\hline TRANS_VAL & $-0,00003$ & $0,0051^{a}$ & TRANS_VAL & $-0,00001$ & $0,0000^{\mathrm{a}}$ \\
\hline SAME_SECT & $-0,5050$ & $0,0138^{\mathrm{b}}$ & SAME_SECT & $-0,0890$ & $0,0427^{\mathrm{b}}$ \\
\hline DOMESTIC_ACQ & $-0,5947$ & $0,0042^{a}$ & DOMESTIC_ACQ & $-0,1314$ & $0,0037^{\mathrm{a}}$ \\
\hline$A C Q P C E \bar{B} I T D A$ & 0,1661 & $0,0003^{a}$ & ACQ PC EBITDA & 0,0001 & $0,0284^{\mathrm{b}}$ \\
\hline OFFER_PREMIUM_1W & 0,0113 & $0,0030^{a}$ & OFFER_PREMIUM_1W & 0,0012 & $0,0206^{\mathrm{b}}$ \\
\hline TARG_LEV & 0,9332 & $0,0430^{\mathrm{b}}$ & TARG_LEV & 0,1169 & 0,2902 \\
\hline DUM_CHALLGED_DEA & 1,2746 & $0,0077^{a}$ & DUM_CHALLGED_DEA & 0,1684 & $0,0008^{\mathrm{a}}$ \\
\hline ASYMMETRY3 & $-0,0560$ & $0,0802^{c}$ & ASYM̄METRY3 & $-0,0221$ & $0,0629^{\mathrm{C}}$ \\
\hline $\mathrm{N}=283$ & & & $N=283$ & & \\
\hline $\log =-102,99$ & & & $\mathrm{R} 2=0,14$ & & \\
\hline
\end{tabular}

Table 13 - Determinants of alternative cash-shares choice

(Dependant is dummy full cash(1)/full share(0) payment; restricted model with 8 variables; Probit estimates; robust covariance estimate are used to adjust for heteroscedasticity; variable definitions: see Table 8; European M\&A transactions; 2000-2010; a: 1\% significance level; b: 5\% significance level; c: $10 \%$ significance level) 


\begin{tabular}{|c|c|c|c|c|c|c|c|c|}
\hline Variable & Coefficient & $p$-val & Variable & Coefficient & $p-v a l$ & Variable & Coefficient & $p-v a l$ \\
\hline Constant & $-0,7471$ & 0,9558 & PERC_SH_ACQD & 0,2632 & $0,0000^{a}$ & PERC_SH_ACQD & 0,2134 & $0,0000^{\mathrm{a}}$ \\
\hline PERC_SH_ACQD & 0,2812 & $0,0027^{a}$ & PERC_CA $\overline{1}$ & 0,1761 & $0,0000^{a}$ & PERC_CA $\overline{1}$ & 0,1590 & $0,0000^{a}$ \\
\hline TRANS_VÁL & $-0,0002$ & 0,1283 & DESEQ & $-0,3941$ & 0,1184 & DESEQ & $-0,4447$ & $0,0105^{b}$ \\
\hline SAME_SECCT & 2,9794 & 0,4617 & TARG_Q & 1,3944 & $0,0017^{a}$ & TARG_Q & 1,1784 & 0,1120 \\
\hline DOMESTIC_ACQ & $-3,9001$ & 0,3742 & DUM_C̄HALLGED_DEA & 17,0925 & $0,0214^{\mathrm{b}}$ & DUM_CEALLGED_DEA & 17,5179 & $0,0022^{a}$ \\
\hline DUM_EU_ZONE & $-9,7539$ & 0,1453 & ASYMMETRY1 & $-0,6691$ & 0,6957 & ASYMMETRY1 & $-1,9458$ & $0,0344^{b}$ \\
\hline ACQ_PC_CASH & $-0,2524$ & 0,3435 & TRANS_VAL & $-0,0003$ & 0,2531 & & & \\
\hline ACQ_PC_EBITDA & 0,0049 & 0,9920 & SAME_SECT & 0,0623 & 0,9870 & & & \\
\hline TARG_PC_E_CASH & 0,6611 & $0,0694^{c}$ & DUM_EU_ZONE & $-8,4132$ & $0,0562^{c}$ & & & \\
\hline FRIEN_ATTITUD & $-7,4393$ & 0,1904 & DUM_SUBSIDIARY & 2,5055 & 0,6379 & & & \\
\hline PERC_CA1 & 0,1485 & 0,4745 & & & & & & \\
\hline DUM_TOE & $-3,5457$ & 0,5552 & & & & & & \\
\hline DESEQ & $-0,3440$ & 0,1468 & & & & & & \\
\hline EBIT_ROA & $-44,4597$ & 0,2285 & & & & & & \\
\hline ACQ_LEV & 0,2357 & 0,9036 & & & & & & \\
\hline TARG_LEV & 9,7053 & 0,4958 & & & & & & \\
\hline$A C Q \_Q$ & 0,4360 & 0,4465 & & & & & & \\
\hline TARG_QQ & 1,2156 & $0,0580^{c}$ & & & & & & \\
\hline DUM_CHALLGED_DEA & 13,0422 & $0,0628^{c}$ & & & & & & \\
\hline DUM_SUBSIDIARY & $-7,5133$ & 0,2729 & & & & & & \\
\hline DUM_CASH & 10,6170 & 0,6223 & & & & & & \\
\hline DUM_HYBRID & 9,5223 & 0,3843 & & & & & & \\
\hline ASYMMETRY1 & 0,6669 & 0,7093 & & & & & & \\
\hline$N=156$ & & & $N=316$ & & & $N=316$ & & \\
\hline $\mathrm{R} 2=0,26$ & & & $\mathrm{R} 2=0,15$ & & & $\mathrm{R} 2=0,14$ & & \\
\hline
\end{tabular}

Table 15 - Determinants of the offer premiums

(Dependant is offer premium in percentage calculated 1 week before the announcement; OLS estimates; robust covariance estimate are used to adjust for heteroscedasticity; variable definitions: see Table 8; European M\&A transactions; 2000-2010; N=a: 1\% significance level; b: 5\% significance level; c: $10 \%$ significance level) 


\begin{tabular}{|c|c|c|c|c|c|}
\hline Panel A & & & & & \\
\hline Dep OFFER_PREMIUM_ & & & Dep PERC_CASH & & \\
\hline Variable & Coefficient & $p$-val & Variable & Coefficient & $p$-val \\
\hline$\overline{\text { PERC_SH_ACQD }}$ & 0,2619 & $0,0000^{a}$ & $\overline{\text { Constant }}$ & 79,5852 & $0,0000^{\mathrm{a}}$ \\
\hline PERC_CĀ 1 & 0,1815 & $0,0000^{a}$ & TRANS_VAL & $-0,0008$ & $0,0052^{\mathrm{a}}$ \\
\hline DESEQ & $-0,4306$ & $0,0898^{c}$ & SAME_SECT & $-7,2093$ & 0,1078 \\
\hline TARG_Q & 1,3516 & $0,0021^{a}$ & DOMESTIC_ACQ & $-16,9655$ & $0,0003^{\mathrm{a}}$ \\
\hline DUM_C̄CHALLGED_DEA & 16,6398 & $0,0230^{b}$ & ACQ_PC_EB-BITDA & 0,0058 & 0,7068 \\
\hline ASYMMETRY1 & $-0,9062$ & 0,5910 & OFFER_PREMIUM_1W & 0,1069 & $0,0936^{c}$ \\
\hline TRANS_VAL & $-0,0003$ & 0,2283 & TOEHOLD & 0,1384 & 0,1609 \\
\hline SAME_SECT & $-0,6179$ & 0,8699 & TARG_LEV & 20,4954 & $0,0393^{b}$ \\
\hline & & & DUM_CHALLGED_DEA & 8,3900 & 0,3087 \\
\hline & & & DUM_SUBSIDIARY & $-0,8896$ & 0,8985 \\
\hline & & & ASYMMETRY1 & $-0,3808$ & 0,8443 \\
\hline $\mathrm{N}=312$ & & & $\mathrm{~N}=312$ & & \\
\hline $\mathrm{R} 2=0,13$ & & & $R 2=0,09$ & & \\
\hline Panel B & & & & & \\
\hline Dep OFFER_PREMIUM_ & & & Dep PERC_CASH & & \\
\hline Variable & $\underline{\text { Coefficient }}$ & $\mathrm{p}$-val & Variable & $\underline{\text { Coefficient }}$ & $\mathrm{p}$-val \\
\hline PERC_SH_ACQD & 0,2157 & 0,0000 & Constant & 66,6328 & $0,0000^{\mathrm{a}}$ \\
\hline PERC_CA1 & 0,1663 & 0,0000 & TRANS_VAL & $-0,0008$ & $0,0059^{\mathrm{a}}$ \\
\hline DESEQ & $-0,4735$ & 0,0591 & ACQ_PC_EBITDA & 0,0086 & 0,5850 \\
\hline TARG_Q & 1,1480 & 0,0067 & TARG_LEV & 20,6861 & $0,0401^{b}$ \\
\hline DUM_CHALLGED_DEA & 17,0109 & 0,0190 & OFFER_PREMIUM_1W & 0,1462 & $0,0228^{b}$ \\
\hline ASYMMETRY1 & $-2,0558$ & 0,1945 & ASYMMETRY1 & $-1,6997$ & 0,3790 \\
\hline & & & DUM_CHALLGED_DEA & 7,1585 & 0,3916 \\
\hline & & & TOEHOLD & 0,1439 & $0,0806^{c}$ \\
\hline $\mathrm{N}=312$ & & & $\mathrm{~N}=312$ & & \\
\hline $\mathrm{R} 2=0,13$ & & & R2 0,05 & & \\
\hline
\end{tabular}

Table 16 - Determinants of offer premiums and percentage for any means of payment - Simultaneous equation estimates over the global sample (Dependants are offer premiums in percentage calculated 1 week before the announcement and percentage paid in cash; linear system of two equations; see equations ( $1 \mathrm{a}-\mathrm{b})$ and $(2 \mathrm{a}-\mathrm{b})$ in the text; robust covariance estimate are used to adjust for heteroscedasticity; variable definitions: see Table 8; European M\&A transactions; 2000-2010; N=a: 1\% significance level; b: 5\% significance level; c: 10\% significance level) 


\begin{tabular}{|c|c|c|c|c|c|}
\hline \multicolumn{6}{|l|}{ Panel A } \\
\hline \multicolumn{3}{|c|}{ Dep OFFER_PREMIUM_1W } & \multicolumn{3}{|l|}{ Dep PERC_CASH } \\
\hline Variable & Coefficient & $p$-val & $\underline{\text { Variable }}$ & Coefficient & $p$-val \\
\hline$\overline{\text { PERC_SH_ACQD }}$ & $\overline{0,2343}$ & $\overline{0}, 0000^{\mathrm{a}}$ & $\overline{\text { Constant }}$ & 87,3147 & $\overline{0}, 0000^{a}$ \\
\hline PERC_CA1 & 0,2266 & $0,0000^{\mathrm{a}}$ & TRANS_VAL & $-0,0008$ & $0,0061^{a}$ \\
\hline DESEQ & $-0,4139$ & 0,1223 & SAME_SECT & $-8,6669$ & $0,0696^{c}$ \\
\hline TARG_Q & 1,2724 & $0,0162^{b}$ & DOMESTIC_ACQ & $-11,9831$ & $0,0146^{b}$ \\
\hline DUM_C̄HALLGED_DEA & 10,8204 & 0,2199 & ACQ_PC_EB'ITDA & 0,0080 & 0,5882 \\
\hline ASYMMETRY1 & $-1,5695$ & 0,4023 & OFFER_PREMIUM_1W & 0,1564 & $0,0147^{\mathrm{b}}$ \\
\hline TRANS_VAL & $-0,0002$ & 0,5213 & TARG_LEV & 9,8302 & 0,3541 \\
\hline SAME_SECCT & $-0,7300$ & 0,8647 & DUM_C̄HALLGED_DEA & 14,6167 & 0,1070 \\
\hline DUM_EU_ZONE & $-8,8572$ & $0,0672^{c}$ & ASYMMETRY3 & $-2,0069$ & $0,0100^{a}$ \\
\hline DUM_SUBSIDIARY & $-0,3900$ & 0,9474 & & & \\
\hline $\mathrm{N}=25 \overline{5}$ & & & $\mathrm{~N}=255$ & & \\
\hline $\mathrm{R} 2=0,13$ & & & $\mathrm{R} 2=0,11$ & & \\
\hline \multicolumn{6}{|l|}{ Panel B } \\
\hline \multicolumn{3}{|c|}{ Dep OFFER_PREMIUM_1W } & \multicolumn{3}{|l|}{ Dep PERC_CASH } \\
\hline Variable & Coefficient & $p$-val & Variable & Coefficient & $p$-val \\
\hline PERC SH ACQD & 0,1911 & $0,0001^{a}$ & Constant & 87,3147 & $0,0000^{a}$ \\
\hline PERC_CA 1 & 0,1972 & $0,0000^{\mathrm{a}}$ & TRANS_VAL & $-0,0008$ & $0,0061^{a}$ \\
\hline DESEQ & $-0,4794$ & $0,0703^{a}$ & SAME_SECT & $-8,6669$ & $0,0696^{\mathrm{C}}$ \\
\hline TARG_Q & 0,9757 & $0,0550^{c}$ & DOMESTIC_ACQ & $-11,9831$ & $0,0146^{b}$ \\
\hline DUM_CHALLGED_DEA & 12,4101 & 0,1564 & ACQ_PC_EBITDA & 0,0080 & 0,5882 \\
\hline \multirow[t]{4}{*}{ ASYMMETRY1 } & $-2,8159$ & 0,1117 & OFFËR_PREMIUM_1W & 0,1564 & $0,0147^{b}$ \\
\hline & & & TARG_LEV & 9,8302 & 0,3541 \\
\hline & & & DUM_CHALLGED_DEA & 14,6167 & 0,1070 \\
\hline & & & ASYMMETRY3 & $-2,0069$ & $0,0100^{a}$ \\
\hline $\mathrm{N}=255$ & & & $\mathrm{~N}=255$ & & \\
\hline $\mathrm{R} 2=0,13$ & & & $\mathrm{R} 2=0,12$ & & \\
\hline
\end{tabular}

Table 17 - Determinants of offer premiums and percentage for full cash/full share payments - Simultaneous linear equation estimates

(Dependants are offer premiums in percentage calculated 1 week before the announcement and percentage paid in cash $(0 \%$ or $100 \%)$; linear system of two equations; see equations $(1 \mathrm{a}-\mathrm{b})$ and $(2 \mathrm{a}-\mathrm{b})$ in the text; robust covariance estimate are used to adjust for heteroscedasticity; variable definitions: see Table 8; European M\&A transactions; 2000-2010; N=a: 1\% significance level; b: 5\% significance level; c: 10\% significance level) 


\begin{tabular}{|c|c|c|c|c|c|}
\hline \multicolumn{6}{|l|}{ Panel A } \\
\hline \multicolumn{3}{|c|}{ Dep OFFER_PREMIUM_1W } & \multicolumn{3}{|l|}{ Dep PERC_CASH } \\
\hline Variable & Coefficient & $p$-val & Variables & Coefficient & $p$-val \\
\hline$\overline{\text { PERC_SH_ACQD }}$ & 0,2311 & $0,0889^{c}$ & $\overline{\text { Constant }}$ & 51,0912 & $0,0001^{a}$ \\
\hline PERC_CA1 & $-0,3002$ & 0,1437 & SAME_SECT & $-4,4922$ & 0,6334 \\
\hline DESEQ & $-1,0003$ & 0,6201 & OFFER_PREMIUM_1W & $-0,3073$ & 0,1526 \\
\hline TARG_Q & 4,0443 & 0,0993 & TOEHOLD & 0,0437 & 0,8916 \\
\hline DUM_CHALLGED_DEA & 33,6948 & $0,0146^{b}$ & $A C Q \_Q$ & $-2,0908$ & 0,3555 \\
\hline ASYMMETRY1 & 0,9525 & 0,8202 & TARG_Q & 4,8004 & 0,3162 \\
\hline TRANS_VAL & $-0,0007$ & $0,0928^{c}$ & DUM_CHALLGED_DEA & 2,8683 & 0,8394 \\
\hline SAME_SECT & 4,1792 & 0,6494 & DESEQ & $-1,4388$ & 0,5094 \\
\hline DUM_EU_ZONE & 9,6868 & 0,4247 & ASYMMETRY1 & 3,6990 & 0,5056 \\
\hline DUM_SUBSIDIARY & 2,7048 & 0,8521 & & & \\
\hline $\mathrm{N}=32$ & & & $\mathrm{~N}=32$ & & \\
\hline $\mathrm{R} 2=0,15$ & & & $\mathrm{R} 2=\mathrm{ns}$ & & \\
\hline \multicolumn{6}{|l|}{ Panel B } \\
\hline \multicolumn{3}{|c|}{ Dep OFFER_PREMIUM_1W } & Dep PERC_CASH & & \\
\hline$\underline{\text { Variable }}$ & $\underline{\text { Coefficient }}$ & p-val & Variable & $\underline{\text { Coefficient }}$ & p-val \\
\hline$\overline{\text { PERC_SH_ACQD }}$ & 0,2987 & $0,0068^{a}$ & $\overline{\text { Constant }}$ & $\overline{51,0912}$ & $0,0001^{a}$ \\
\hline PERC_CĀ1 & $-0,2390$ & 0,1566 & SAME_SECT & $-4,4922$ & 0,6334 \\
\hline DESEQ̄ & $-0,2526$ & 0,8806 & OFFER_PREMIUM_1W & $-0,3073$ & 0,1526 \\
\hline TARG_Q & 3,2981 & 0,1476 & TOEHOLD & 0,0437 & 0,8916 \\
\hline DUM_CHALLGED_DEA & 23,1298 & $0,0484^{b}$ & ACQ_Q & $-2,0908$ & 0,3555 \\
\hline \multirow[t]{4}{*}{ ASYMMETRY1 } & 1,4349 & 0,7006 & TARG_Q & 4,8004 & 0,3162 \\
\hline & & & DUM_CHALLGED_DEA & 2,8683 & 0,8394 \\
\hline & & & DESEQ & $-1,4388$ & 0,5094 \\
\hline & & & ASYMMETRY1 & 3,6990 & 0,5056 \\
\hline $\mathrm{N}=32$ & & & $\mathrm{~N}=32$ & & \\
\hline $\begin{array}{l}\mathrm{R} 2=0,16 \\
\text { Panel C }\end{array}$ & & & $\mathrm{R} 2=\mathrm{ns}$ & & \\
\hline \multicolumn{3}{|c|}{ Dep OFFER PREMIUM $1 \mathrm{~W}$} & Dep PERC_CASH & & \\
\hline Variable & Coefficient & $p$-val & Variable & Coefficient & $p$-val \\
\hline$\overline{\text { PERC_SH_ACQD }}$ & 0,2446 & $0,0001^{a}$ & 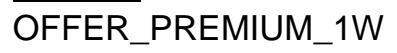 & 0,4695 & $0,0012^{\mathrm{a}}$ \\
\hline TARG_Q & 3,3741 & $0,0198^{b}$ & SAME_SECT & 23,7547 & $0,0026^{a}$ \\
\hline TRANS__VAL & $-0,0006$ & 0,1292 & ACQ_EBEITDA & 0,0026 & $0,0279^{b}$ \\
\hline DUM_CHALLGED_DEA & 22,3073 & $0,0547^{c}$ & & & \\
\hline $\mathrm{N}=51$ & & & $\mathrm{~N}=51$ & & \\
\hline $\mathrm{R} 2=0,15$ & & & $\mathrm{R} 2=\mathrm{ns}$ & & \\
\hline
\end{tabular}

Table 18 - Determinants of offer premiums and percentage for hybrid payments Simultaneous linear equation estimates

(Dependants are offer premiums in percentage calculated 1 week before the announcement and percentage paid in cash( $0 \%$ or $100 \%)$; linear system of two equations; see equations (1ab) and (2a-b) in the text; robust covariance estimate are used to adjust for heteroscedasticity; variable definitions: see Table 8; European M\&A transactions; 2000-2010; N=a: 1\% significance level; b: 5\% significance level; c: 10\% significance level)

References

\begin{tabular}{|l|l|}
\hline Bebchuk L.A. & $\begin{array}{l}\text { (1994) Efficient and Inefficient Sales of Corporate Control, } \\
\text { Quarterly Journal of Economics, vol. 109, p.957-993. }\end{array}$ \\
\hline Belot F. & $\begin{array}{l}\text { (2010) Target Shareholder agreements, takeover premium, } \\
\text { and acquisition likelihood, working paper, University Paris }\end{array}$ \\
\hline
\end{tabular}




\begin{tabular}{|c|c|}
\hline & Dauphine \\
\hline Ben-Amar W., P. André, & $\begin{array}{l}\text { (2009) Control Threat and Means of Payment: } \\
\text { Evidence from Canadian Mergers and Acquisitions Large } \\
\text { shareholder and form of payment in M\&A: Evidence from } \\
\text { Canada, working paper, } 2009 \text { EFMA Symposium on } \\
\text { Corporate governance, Milano }\end{array}$ \\
\hline Berkovitch E., Narayanan M., & $\begin{array}{l}\text { (1990) Competition and the medium of exchange in } \\
\text { takeovers, Review of Financial Studies, vol.3, p.153-174. }\end{array}$ \\
\hline Betton S., Eckbo B. & $\begin{array}{l}\text { (2000)"Toeholds, bid jumps, and expected payoffs in } \\
\text { takeovers", Review of Financial Studies, vol.13, p.841-822 }\end{array}$ \\
\hline $\begin{array}{l}\text { Burkart, M., D. Gromb, F. } \\
\text { Panunzi }\end{array}$ & $\begin{array}{l}\text { (2000) Agency Conflicts in Public and Negotiated } \\
\text { Transfers of Corporate Control, Journal of Finance, 2000, } \\
\text { vol. 55, p.647-677. }\end{array}$ \\
\hline Burkart, M., F. Panunzi & $\begin{array}{l}\text { (2004), Mandatory bids, squeeze-out, sell-out and the } \\
\text { dynamic of tender offer process, in G. Ferrarini et al. (eds), } \\
\text { Modern company and takeover law in Europe, 2004, } \\
\text { p.737-765, Oxford University Press, Oxford. }\end{array}$ \\
\hline $\begin{array}{l}\text { Carleton W., Guilkey } \\
\text { Harris R., Stewart J }\end{array}$ & $\begin{array}{l}\text { (1983) An empirical analysis of the role of the medium of } \\
\text { exchange in mergers, Journal of Finance, vol. 38, p.813- } \\
826\end{array}$ \\
\hline Chang S., E. Mais & $\begin{array}{l}\text { (1998) Managerial motives and merge financing, The } \\
\text { Financial Review, 2000, vol. } 35 \mathrm{n}^{\circ} 4 \text {, p.139-152 }\end{array}$ \\
\hline Cheng P., Li J., Tong W. & $\begin{array}{l}\text { (2008)., Information Asymmetry in the Takeover Market, } \\
\text { 2008, EFMA working paper, www.ssrn.com }\end{array}$ \\
\hline Chevalier A., Redor E & $\begin{array}{l}\text { (2010) The determinants of payment method choice in } \\
\text { cross-border acquisitions", Bankers, Markets Investors, } \\
\mathrm{n}^{\circ} 106 \text {, june, } 4-14\end{array}$ \\
\hline Chevalier A., Redor E & $\begin{array}{l}\text { (2007)., Les théories expliquant le choix de la méthode de } \\
\text { paiement dans le cadre d'une opération de fusion- } \\
\text { acquisition, Banques et Marchés, mai-juin 2007, n }{ }^{\circ} 88 \text {, } \\
\text { p.46-54. }\end{array}$ \\
\hline Cornu P., Isakov D. & $\begin{array}{l}\text { (2000) The deterring role of the medium of payment in } \\
\text { takeover contests: Theory and evidence from the UK", } \\
\text { European Financial Management, vol. 6., } 423-440\end{array}$ \\
\hline $\begin{array}{l}\text { Eckbo E., Giammarino R., } \\
\text { Heinkel R }\end{array}$ & $\begin{array}{l}\text { (1990) Asymmetric information and the medium of } \\
\text { exchange in takeovers; Theory and tests, Review of } \\
\text { Financial Studies, vol. 3, p.651-675 }\end{array}$ \\
\hline Faccio M., Lang L. & $\begin{array}{l}\text { (2002) The ultimate ownership of western European } \\
\text { corporations, Journal of Financial Economics, vol. 65, p. } \\
365-395\end{array}$ \\
\hline Faccio M., Masulis R. & $\begin{array}{l}\text { (2005) The choice of payment method in European } \\
\text { mergers and acquisitions", Journal of Finance, vol. 60(3), } \\
\text { p.1345-1388 }\end{array}$ \\
\hline Fishman M. & $\begin{array}{l}\text { (1989) Preemptive bidding and the role of the medium of } \\
\text { exchange in acquisitions, Journal of Finance, } 44,41-571\end{array}$ \\
\hline Goergen M., Renneboog L & $\begin{array}{l}\text { (2004)., Shareholder wealth effects of European domestic } \\
\text { and cross-border takeover bids, European Financial } \\
\text { Management, vol. 10, no 1, p.243-268 }\end{array}$ \\
\hline Goldman E., Qian J. & $\begin{array}{l}\text { (2004) Optimal toeholds in takeover contest, working } \\
\text { paper, University of North Carolina, March }\end{array}$ \\
\hline
\end{tabular}




\begin{tabular}{|c|c|}
\hline Hansen R. & $\begin{array}{l}\text { (1987) A theory for the choice of exchange medium in } \\
\text { mergers and acquisitions, Journal of Business, } 60,75-95\end{array}$ \\
\hline La Bruslerie H. de & $\begin{array}{l}\text { (2010) Corporate acquisition process: Is there an optimal } \\
\text { cash-equity payment mix?, working paper, University Paris } \\
\text { Dauphine }\end{array}$ \\
\hline $\begin{array}{l}\text { La Porta R., Lopez-de-Silanes } \\
\text { F., Shleifer A., Vishny R. }\end{array}$ & $\begin{array}{l}\text { (1998) Law and finance, Journal of Political Economy, } \\
\text { vol. 106, n }{ }^{\circ} 6, \text { p1113-1155 }\end{array}$ \\
\hline Linn S.C., Switzer J.A. & $\begin{array}{l}\text { (2001) Are cash acquisitions associated with better post } \\
\text { combination operating performance than stock } \\
\text { acquisitions? Journal of Banking and Finance, vol. 25, p. } \\
\text { 1113-1138. }\end{array}$ \\
\hline Martin K.J. & $\begin{array}{l}\text { (1996) The method of payment in corporate acquisitions, } \\
\text { Investment Opportunities, and Management Ownership, } \\
\text { Journal of Finance, vol. 51, no 4, p.1227-1246. }\end{array}$ \\
\hline Martynova M., Renneboog L. & $\begin{array}{l}\text { (2009) What determines the financing decision in } \\
\text { corporate takeovers: Cost of capital, agency problems, or } \\
\text { the means of payment", Journal of Corporate Finance, 15, } \\
290-315\end{array}$ \\
\hline Martynova, M., Renneboog, L & $\begin{array}{l}\text { (2006) Mergers and acquisitions in Europe: the fifth } \\
\text { takeover wave. In: Renneboog, L. (Ed.), Advances in } \\
\text { Corporate Finance and Asset Pricing, 2006, Elsevier, } \\
\text { Amsterdam, p. 15-75 }\end{array}$ \\
\hline $\begin{array}{l}\text { Moeller S., Schlingemann F., } \\
\text { Stulz R. }\end{array}$ & $\begin{array}{l}\text { (2005) Wealth Destruction on a Massive Scale? A Study of } \\
\text { Acquiring-Firm Returns in the Recent Merger Wave, } \\
\text { Journal of Finance, Vol. } 60, n^{\circ} 2 \text {, p. } 757-782\end{array}$ \\
\hline Myers S., Majluf N. & $\begin{array}{l}\text { (1984) Corporate financing and investment decisions when } \\
\text { firms have information that investors do not have, Journal } \\
\text { of Financial Economics, 1984, vol. 13, p.187-221 }\end{array}$ \\
\hline Officer M. & $\begin{array}{l}\text { (2003) "Termination fees in mergers and acquisitions", } \\
\text { Journal of Financial Economics, 69, 431-467 }\end{array}$ \\
\hline Song M., Walking R. & $\begin{array}{l}\text { (1993) The Impact of Managerial Ownership on } \\
\text { Acquisition Attempts and Target Shareholder Wealth , } \\
\text { Journal of Financial and Quantitative Analysis, vol.28, p. } \\
\text { 439-457 }\end{array}$ \\
\hline Stulz R. & $\begin{array}{l}\text { (1988) Managerial control of voting rights: Financing } \\
\text { policies and the market for corporate control, Journal of } \\
\text { Financial economics, vol.20, p.25-54 }\end{array}$ \\
\hline Stulz R., Walking R., Song M. & $\begin{array}{l}\text { (1990) The distribution of target ownership and the } \\
\text { division of gains in successful takeovers, Journal of } \\
\text { Finance, vol. } 45, \text { p. } 817-83\end{array}$ \\
\hline Sundarsanam S. & $\begin{array}{l}\text { (1996) Target shareholder, takeovers and target valuation, } \\
\text { Journal of Business, Finance and Accounting, vol.23, } \\
\text { p.295-314 }\end{array}$ \\
\hline Travlos N. & $\begin{array}{l}\text { (1987) "Corporate takeover bids, method of payment, and } \\
\text { acquiring firm's stock returns", Journal of Finance, 42, } \\
943-963\end{array}$ \\
\hline Volpin P. & $\begin{array}{l}\text { (2002) Governance with poor investor protection: evidence } \\
\text { from top executive turnover in Italy" Journal of Financial } \\
\text { Economics, 64, 61-90 }\end{array}$ \\
\hline
\end{tabular}


ANNEX 1

Deal Value (\$ Mil)

Target Nation (Code)

Acquirer Nation Region Include Japan, Europe, North America

(Code)

Acquisition Techniques Include

(Code)

Target or Acquirer Macro Industry (Code)

Deal Status (Code)

Consideration Sought (Codes) Include

Consideration

Category (Code)

Acquirer Public Status (Code)

Target Public Status (Code)
Between 50 to $\mathrm{HI}$

Include France, Germany, United Kingdom, Spain, Belgium, Netherlands, Italy

Mandatory Offering, Private Tender

Offer, Merger of Equals,

Tender/Merger, Tender Offer,

Privately Negotiated Purchase, Open

Market Purchase, Exchange Offer

Exclude Financials, Government and Agencies

Include Completed, Unconditional

Common Stock, Warrants, Stock,

Convertible Bond, Ordinary Share

Cash, Common/Ordinary Shares

Include Public

Include Public

Annex 1 Criteria used to select takeover (dates of deals between 01/01//2000 and 01/05/2010; source: Thomson One Banker) 